\title{
EDUCATIONAL MALPRACTICE
}

\section{INTRODUCTION}

In 1959, Columbia University sued a student and his parents to recover $\$ 1,000$ for tuition owed to the university. ${ }^{1}$ The student filed a counterclaim demanding damages of $\$ 7,016$, alleging that the university "had represented that it would teach the defendant wisdom, truth, character, enlightenment, understanding, justice, liberty, honesty, courage, beauty and similar virtues and qualities; that it would develop the whole man, maturity, well-roundedness, objective thinking and the like; and that because it failed to do so it was guilty of misrepresentation, to defendant's pecuniary damage." ${ }^{\prime 2}$ The trial court granted the university's motion for summary judgment and was sustained on appeal. ${ }^{3}$

In 1972, a young man with an average or above average IQ and an average attendance record was graduated from a San Francisco public high school after having attended San Francisco public schools for twelve years. He had a reading ability of approximately fifth-grade level. ${ }^{4}$ During his period of attendance in the San Francisco public schools, the student's parents attempted to obtain information about his educational progress and were repeatedly assured that he was performing at or near grade level. ${ }^{5}$ The student, alleging that his inability to read and write resulted from the negligence of his teachers and other school district employees, ${ }^{6}$ sued the school district and its employees to recover damages of over $\$ 500,000 .{ }^{7}$ The trial judge sustained a demurrer to the complaint without opinion, ${ }^{8}$ and the case is now on appeal.

1 Trustees of Columbia Univ. v. Jacobsen, 53 N.J. Super. 574, 148 A.2d 63 (App. Div.), aff'd, 31 N.J. 221, 156 A.2d 251 (1959).

${ }^{2}$ Id. at $576,148 \mathrm{~A} .2 \mathrm{~d}$ at 64.

${ }^{3} I d$.

${ }^{4}$ First Amended Complaint at 4-5, Doe v. San Francisco Unified School Dist., No. 653-312 (Cal. Super. Ct., Sept. 6, 1974) [hereinafter cited as Complaint].

${ }^{5} I d$.

6 Plaintiff's Memorandum in Response to Defendants' Demurrer at 1, Doe v. San Francisco Unified School Dist., No. 653-312 (Cal. Super. Ct., Sept. 6, 1974) [hereinafter cited as Plaintiff's Memorandum].

${ }^{7}$ Complaint, supra note 4 , at 17.

${ }^{8}$ Doe v. San Francisco Unified School Dist., No. 653-312 (Cal. Super. Ct., Sept. 6, 1974), appeal docketed, Civil No. 36851, Ist Dist. Ct. App., Apr. 28, 1975. 
Although aspects of each of these suits may seem frivolous or implausible, these cases raise the issue whether a student can recover from a teacher, an administrator, a school, or school district for his failure to learn because of teacher negligence or incompetence. ${ }^{9}$ This Comment will explore various theories upon which a student might base such a suit. It will focus on the public school context in order to allow the development of the fullest range of legal theories and policy arguments and to present most of the legal and policy objections that can be raised against such a suit.

There is virtually no law in this area. The legal basis for this kind of action will be constructed from general principles of tort and contract law and by analogy to the law of professional malpractice. This Comment will outline a broad range of arguments, will indicate the strengths and weaknesses of each argument, and will suggest the situations in which each argument would be most useful.

\section{Public Schools}

In the public school context, an action for failure to learn addresses the general problem of providing a remedy to public school students for the loss of educational benefits because teachers negligently or intentionally failed to conform to minimum standards of professional competence in the same or similar communities. ${ }^{10}$ This loss of educational benefits results in the harm of the failure of a student or class of students to attain the educational level they probably would have attained had their teacher performed at the required level. Such a suit does not rest on the assumption that students will not learn at all without teachers or even that teachers are the most significant determinant of how much children learn. ${ }^{11}$ The harm that a suit of this type could be brought to remedy is the loss of the difference a teacher makes in how much a student learns.

Because the standard to be applied is based on the minimum acceptable level of competence existing within the community or comparable communities, such a suit is probably not an effective approach to a general upgrading of education in a

\footnotetext{
${ }^{9}$ See Suing for Not Learning, Time, Mar. 3, 1975, at 73, describing a University of Bridgeport student's suit to recover tuition, the cost of books, driving expenses, and legal fees. The student alleged that a required course was "worthless," that the school did not provide the course described in the catalog, and that she did not learn anything.

${ }^{10}$ See text accompanying notes 94-104 infra.

${ }^{11}$ See generally C. Jencks, INEQUaLIty (1972).
} 
community or to an equalization of per capita funding, teacher quality, and facilities among different schools or communities. ${ }^{12}$ In other words, a student could not bring an action for failure to learn alleging that his school is inferior to one in a dissimilar district, but such a suit might be brought, for example, by a student or class of students in a prosperous community who fail to reach the eightieth percentile in a particular subject or by students in a poor school who are graduated from high school reading at a third-grade level. ${ }^{13}$ In either situation, a student may have been denied the benefit of minimally competent instruction and suffered the "harm" of not learning as much as he would have if the teacher had been competent.

\section{A. Remedies}

At least three kinds of relief might be sought in the public school context. A plaintiff might seek removal of an incompetent teacher (and replacement with a competent teacher); provision of, or payment for, remedial instruction; and/or monetary compensation for diminished future income due, for example, to plaintiff's relegation to menial employment because of his inferior education.

Removal of an incompetent teacher has the advantage of being relatively cost-free. Teacher contracts may contain a provision permitting dismissal "for cause," and a judicial finding of negligence or incompetence might permit invocation of the provision. ${ }^{14}$ Also, under the common law and/or statutes of most states, teachers (including tenured teachers) can be dismissed for incompetence. ${ }^{15}$ An injunction could be directed against either school officials, ordering dismissal, or against the teacher, enjoining him or her from teaching. This remedy seems to be available under the tort, contract, and possibly the mandamus theories which will be developed later in this Comment. ${ }^{16}$ While dismissal eliminates the possibility that the teacher will harm future students, however, it does nothing to make whole those students who have already been subjected to the teacher. This remedy also does not seem suitable where the reasons for the negligent performance are not of a continuing nature, that is, where there

12 For a brief discussion of approaches to these broader problems, see Ratner, Remedying Failure to Teach Basic Skills, InEQUality in Educ., June 1974, at 15.

${ }^{13}$ See text accompanying notes 94-104, 237-40 infra.

${ }^{14}$ See E. Reutter \& R. Hamilton, The Law of Public Education 450 (1970).

${ }^{15} I d$.

${ }^{16}$ See text accompanying notes 76-218 infra. 
is no strong likelihood that the teacher's performance will continue to be unsatisfactory.

Requiring a teacher, school, or school district to provide or pay for remedial instruction sufficient to bring the plaintiffstudents up to the educational level they probably would have attained if they had had a minimally competent teacher ${ }^{17}$ has several advantages. First, plaintiffs would, in most cases, be made whole. Second, this remedy does not involve awarding "speculative damages." 18 Third, given the probable infrequency of successful suits under the standards developed in this Comment, this remedy does not involve ruinous expense to the school district.

In the case of students who have been out of school for a number of years, remedial instruction might not fully compensate the students for the loss suffered. Suppose, for example, that the suit is based on the incompetence of an entire reading staff. The students left school reading (on average) at the thirdgrade level. With minimally competent instruction, they probably would have read at ninth-grade level. ${ }^{19}$ If these students have suffered several years of diminished earnings because of their lack of reading ability, remedial instruction alone will not provide compensation. In such a case, money damages for lost earnings might be sought. Damages would amount to the difference between plaintiff's actual earnings from the time of leaving defendant school to the point at which remedial instruction corrected the reading deficiency and his probable earnings during the same period had he not had a "teacher-caused" educational deficiency. ${ }^{20}$ If the reading deficiency was never corrected, the damages might be the total diminution of plaintiff's lifetime earnings attributable to teacher negligence or incompetence. ${ }^{21}$ In the case of someone who was denied promotion specifically because of his "teacher-caused" educational deficiency, and was consequently relegated to an inferior position, damages might be the difference between his projected life-time earnings at the lower level and what he would have earned in the position he

${ }^{17}$ See text accompanying notes 219-55 infra.

${ }^{18}$ See id.

${ }^{19} \mathrm{Id}$.

${ }^{20} \mathrm{Id}$. Presumably statistics correlating income and reading ability have been or could be compiled. This kind of relief should be sought only where an entire reading or math program was negligently taught, since it is doubtful that a single teacher's negligence could substantially affect a student's earning capacity.

${ }^{21}$ See Complaint, supra note 4, at 19 . The amount of lost earnings may be calculable on the basis of statistics comparing average lifetime earnings of people at one reading level with the earnings of people reading on a higher level. 
was denied, or the difference in earnings during the period between the denial of promotion and remedy of the deficiency. ${ }^{22}$

Numerous objections can be raised to the demand and award of monetary compensation for diminished earnings. First, proof of harm on an individual basis would be difficult if not impossible, even though the harm to the entire class might be demonstrable. ${ }^{23}$ Second, in any individual case, even if harm is proven, the precise amount of damages necessarily would be speculative. Courts have refused to award damages which will eventually be of a fixed amount and susceptible of precise computation, but are nonascertainable at the time of trial. ${ }^{24}$ Third, damages arguably should never exceed the combination of the cost of remedial instruction and earnings lost during the period of remedial instruction; before suffering an income loss, a plaintiff could have sought and paid for remedial instruction. Failure to have done so might be considered a negligent failure to avoid or minimize damages, possibly barring recovery for the avoidable damages. ${ }^{25}$ Finally, the award of money damages for diminished earnings could be a potentially crushing burden upon a school district, especially in a class action. ${ }^{26}$ In decid-

${ }^{22}$ If the suit is brought under a contract theory, the damages recoverable would be either compensation for detriment suffered (e.g., loss of earnings during the period a student who decides not to drop out of school attends school) or loss of the expected benefit of the bargain (e.g., diminished future income).

${ }^{23}$ This greater ease in proving harm to the entire class would support a decision to bring a class action. The other advantages of the class action for this type of suit are (1) the reduced cost per student-plaintiff of a class action and (2) the increased possibility that the publicity generated by a class action could provoke political, legislative, or administrative action potentially more far-reaching than any judicially constructed remedy. See Ratner, supra note 12 , at 16, 21 \& n.20. The disadvantage of a class action is that the potential cost to the school district of a plaintiff's verdict and the antipathy and impatience that some judges feel toward class actions in general, e.g., Katz v. Carte Blanche Corp., 496 F.2d 747 (3d Cir.) (Seitz, C.J., dissenting), cert. denied, 419 U.S. 885 (1974), may severely jeopardize chances of success on the liability issue.

${ }^{24}$ E.g., Big Rock Mountain Corp. v. Stearns-Roger Corp., 388 F.2d 165, 170 (8th Cir. 1968); Fireside Marshmallow Co. v. Frank Quinlan Constr. Co., 213 F.2d 16 (8th Cir. 1954); Sioux Tribe v. United States, 84 Ct. Cl. 16 (1936), cert. denied, 302 U.S. 740 (1937) (court refused to award damages to Indian children for Government's breach of treaty obligation to provide educational facilities and competent teachers, because amount of damages could not be calculated with sufficient certainty). This dislike for speculative damages contrasts with the willingness of courts to allow juries to speculate on the monetary value of pain and suffering, which will never be precisely calculable.

${ }^{25}$ See W. Prosser, Handbook of the Law of Torts, § 65, at 422-24 (4th ed. 1971). This argument loses its strength in the context of a misrepresentation case in which the plaintiff alleges, for example, that he was passed through every grade with satisfactory reports and it was not until after graduation that he realized his deficiencies. See text accompanying notes 169-81 infra; see generally W. PROSSER, supra $\$ 110$.

${ }^{26}$ In Doe v. San Francisco Unified School Dist., No. 653-312 (Cal. Super. Ct., Sept. 6, 1974), appeal docketed, Civil No. 36851, 1st Dist. Ct. App., Apr. 28, 1975, damages 
ing whether to impose liability on the basis of legal theories as novel as those upon which a plaintiff must rely in a suit for failure to learn, a court would certainly consider the potential crippling effect of a large damage award on public education. By demanding money damages for lost earnings, past and future, a plaintiff might diminish his chances of success on the basic liability issues. ${ }^{27}$ It might, therefore, be advisable either to bring a suit for money damages only where remedial instruction would not be feasible, or to defer demands for money damages for diminished earnings to suits brought after liability has been established in suits for teacher dismissal and remedial instruction.

In Doe v. San Francisco Unified School District, the plaintiff sought money damages for mental distress, pain, and suffering arising from his "teacher-caused" reading deficiency. ${ }^{28}$ Although courts have recently recognized the intentional infliction of mental distress as a basis for tort recovery, ${ }^{29}$ courts generally have not permitted recovery for negligently inflicted mental distresss without accompanying physical injury. ${ }^{30}$ The demand in Doe seems to go far beyond any recovery allowed by courts in negligence suits, but it might be made more realistically in an intentional tort action. ${ }^{31}$ Even in the latter case, however, difficulties of proof may make success on this demand highly unlikely; moreover, seeking damages for mental distress may jeopardize chances for success on the crucial liability question.

\section{B. Policy}

A student's suit for failure to learn because of teacher negligence or incompetence ${ }^{32}$ cannot be won with formal legal arguments alone. Part of any plaintiff's case will have to be social policy arguments demonstrating why there should be liability.

Although the extent to which denial of education is an injury cognizable in tort or contract is unclear, courts have recognized the denial of education as a significant loss to a student. ${ }^{33}$

for lost earnings, mental distress, and pain and suffering were calculated by the plaintiff to be $\$ 500,000$. Complaint, supra note 4 , at 19 .

${ }^{27}$ Interview with John G. Harkins, Jr., prominent Philadelphia trial attorney, in Philadelphia, Oct. 17, 1974.

${ }^{28}$ Complaint, supra note 4, at 19. See generally Ratner, supra note 12 , at 16-17.

${ }^{29}$ W. Prosser, supra note 25, § 12.

${ }^{30} I d$. § 54, at 328-30.

${ }^{31}$ See text accompanying notes 164-68 infra.

${ }^{32}$ See text accompanying notes 69-218 infra.

${ }^{33}$ Cf. Sioux Tribe v. United States, 84 Ct. Cl. 16 (1936), cert. denied, 302 U.S. 740 (1937). 
As the Supreme Court stated in Brown v. Board of Education, ${ }^{34}$

Today, education is perhaps the most important function of state and local governments. Compulsory school attendance laws and the great expenditures for education both demonstrate our recognition of the importance of education to our democratic society. It is required in the performance of our most basic public responsibilities, even service in the armed forces. It is the very foundation of good citizenship. Today it is a principal instrument in awakening the child to cultural values, in preparing him for later professional training, and in helping him to adjust normally to his environment. In these days, it is doubtful that any child may reasonably be expected to succeed in life if he is denied the opportunity of an education. ${ }^{35}$

Given the importance of education, lack of legal precedent should not be determinative. In the past, courts have expanded the tort law to create remedies for injuries not previously recognized in tort. Prosser writes,

The law of torts is anything but static, and the limits of its development are never set. When it becomes clear that the plaintiff's interests are entitled to legal protection against the conduct of the defendant, the mere fact that the claim is novel will not of itself operate as a bar to the remedy. ${ }^{36}$

Courts have imposed liability for the intentional infliction of mental suffering, ${ }^{37}$ for injuries caused by defective products, ${ }^{38}$ for the infliction of prenatal injuries, ${ }^{39}$ and for other injuries which do not fit into traditional tort categories. Thus if a plaintiff can convince a court that there should be liability as a matter of policy, the absence of formal legal precedents should not bar recovery in tort. ${ }^{40}$

The primary function of the tort law is, as Prosser explains, "the allocation of losses arising out of human activities . .."41 In

${ }^{34} 347$ U.S. 483 (1954).

${ }^{35}$ Id. at 493.

${ }^{36} \mathrm{~W}$. Prosser, supra note $25, \S 1$, at 3-4 (footnote omitted).

${ }^{37} I d . \S 12$.

${ }^{38} I d . \$ \$ 95-104$.

${ }^{39} I d . \S \S 55$.

${ }^{40}$ For a model of how to fashion a new tort with a combination of policy and formal legal arguments, see Sax \& Hiestand, Slumlordism as a Tort, 65 MICH. L. REv. 869 (1967). See also W. Prosser, supra note $25, \S 1$, at $4 \mathrm{n} .18, \S 12$, at 51 .

${ }^{41} \mathrm{~W}$. Prosser, supra note $25, \S 1$, at 6 . 
deciding if there should be liability in an action for failure to learn, we are deciding who should bear the educational "losses" caused by teacher negligence or incompetence.

Punishment or retaliation has been suggested as one aim of the tort law, that is, as one principle for deciding who should pay for losses. ${ }^{42}$ If the cost of making whole the student who has failed to learn because of teacher negligence is to be assigned in accordance with a punishment or retaliation principle, a blameworthy teacher or school district should bear the loss rather than the innocent student.

Some authorities suggest that losses should be assigned to the party better able to bear the costs, or should be shifted to the public at large. ${ }^{43} \mathrm{~A}$ school district is obviously a better loss bearer than an individual student because it can pass on the cost of whatever remedy is awarded to the general public in the form of increased taxes. Rather than raising taxes, however, a municipality might lower the overall quality of education to pay for a major judgment in favor of a single student or class of students. But even if this were the case, spreading the injury among all students in the district or municipality is arguably more equitable than leaving the entire burden on the student(s) who had the misfortune of drawing an incompetent teacher. Furthermore, just as school districts are able to obtain liability insurance to cover physical injuries to students caused by the negligence of school employees, they could probably obtain insurance against the type of liability involved here, guaranteeing efficient cost spreading. ${ }^{44}$ Even if, because of an immunity statute, ${ }^{45}$ the school district is not held liable for the consequences of the teacher's negligence under the doctrine of respondeat superior or for its own negligence in hiring an incompetent teacher, malpractice insurance could be made available to teachers. The cost of the insurance could be passed on to the public through the mechanism of increased salaries paid with higher taxes. ${ }^{46}$ Thus, the teacher himself appears to be a better risk bearer than the student.

${ }^{42} I d . \S 4$, at $23 \& \mathrm{n} .81$.

${ }^{43}$ See id. 22 \& n.69.

${ }^{44}$ See Proehl, Tort Liability of Teachers, in Professional Negligence 185, 202-03 (T. Roady \& W. Andersen eds. 1960). Some cases and statutes now recognize that the availability of liability insurance eliminates the need to protect governments with immunity. Johnston v. Girvin, 61 Ill. App. 2d 47, 208 N.E.2d 894 (1965); Thomas v. Broadlands Community Consol. School Dist., 348 Ill. App. 567, 109 N.E.2d 636 (1952); Vendrell v. School Dist., 226 Ore. 263, 360 P.2d 282 (1961).

${ }^{45}$ Notes 70-75 infra \& accompanying text.

${ }^{46} C f$. Proehl, supra note 44, at $202 \&$ n. 100. 
It has been suggested that imposing liability for a student's failure to learn because of teacher negligence or incompetence would render public education economically infeasible. ${ }^{47}$ For three reasons, this concern may be unjustified. First, this objection is inapplicable to demands for dismissal of incompetent teachers. Second, although a large class action suit would expose a school district to a potentially crushing burden if damages for prospective loss of income were awarded, the burden would not be nearly as great if only provision of or payment for remedial instruction were demanded. Third, since under the standards of negligence suggested in this Comment ${ }^{48}$ a successful suit would probably be rare, the school district or individual teacher might be able to purchase insurance at a reasonable price. ${ }^{49}$

It is possible that the costs of compensating a class of students or a single student for diminished income would, if provable, be so potentially burdensome as to make success on the liability question unlikely. If a damage judgment would substantially reduce the quality of services that the school district could provide, courts will most likely decide that the social need for educational services outweighs the interest of any particular plaintiff or class of plaintiffs in recovering for educational benefits denied by teacher negligence.

An obvious benefit of imposing liability on teachers, school officials, and school districts is the deterrence of negligent teaching and the hiring of incompetent teachers. ${ }^{50}$ Personal liability, however, may also discourage people from becoming teachers. ${ }^{51}$ Although the availability of malpractice insurance may substantially eliminate fear of financial responsibility, it would not eliminate the "chilling effect" on entry into the profession generated by the fear of being disgraced in a courtroom by public testimony of incompetence.

Furthermore, liability resulting in monetary damages or dismissal may discourage the experimentation that leads to edu-

47 Demurrer of Defendants on First Amended Complaint at 17, Doe v. San Francisco Unified School Dist., No. 653-312 (Cal. Super. Ct., Sept. 6, 1974) [hereinafter cited as Defendants' Demurrer]. See also W. Prosser, supra note 25, § 4, at 22-23.

48 Text accompanying notes 94-104 infra.

${ }^{49}$ See generally Proehl, supra note 44, at 202.

${ }^{\text {so }}$ Cf. Johnson v. State, 69 Cal. 2d 782, 447 P.2d 352, 73 Cal. Rptr. 240 (1968), in which the California supreme court found this consideration persuasive: "An employee in a private enterprise naturally gives some consideration to the potential liability of his employer, and this attention unquestionably promotes careful work; the potential liability of a governmental entity, to the extent that it affects primary conduct at all, will similarly influence public employees." Id. at 792-93, 447 P.2d at 360, 73 Cal. Rptr. at 248.

${ }^{51}$ See Comment, Professional Negligence, 121 U. PA. L. Rev. 627, 657 (1973) [hereinafter cited as Professional Negligence]. 
cational progress. ${ }^{52}$ This problem may be overcome by giving parents the choice of putting their children in experimental classes; the doctrine of assumption of risk would then allow experimentation undeterred by the threat of damages or dismissal. ${ }^{53}$ The threat of liability would have the beneficial effect of inducing school officials and teachers to explain experimental programs to parents and students in order to secure formal and voluntary consent sufficient to establish assumption of risk. Where, in the absence of formal consent, a teacher or school official decides to deviate from conventional practices, and, as a result, children suffer an educational loss, perhaps the victims of the unsuccessful experiment should be compensated or elevated to the educational level they probably would have attained with conventional instruction. ${ }^{54}$ Depending on the circumstances of the particular case, a successful suit need not result in an injunction against experimentation or dismissal of the experimenting teacher. Payment for the costs of the unsuccessful experiment may, in many cases, be sufficient. ${ }^{\mathbf{5 5}}$

It might be argued that other, non-judicial mechanisms, such as political action, certification procedures, supervisory control, and professional review, are adequate to prevent or deter teacher negligence. ${ }^{56}$ But to the extent that an educational malpractice suit has a basis in fact, these other mechanisms have been inadequate to prevent teacher negligence. In addition, most other procedures provide only prospective relief and none of them "make whole" students who have already been injured by teacher negligence. ${ }^{57}$ Professional review boards have been suggested as a cheaper and more efficient way of enforcing professional standards and compensating individuals than the civil lawsuit. ${ }^{58}$ Although fashioning an alternative compensation procedure may be desirable to eliminate the problems inherent in litigation-a slow, costly, and inefficient route ${ }^{59}$-the shortcomings of the judicial process are not a valid reason to deny recovery in a lawsuit.

52 Cf. Wade, The Attorney's Liability for Negligence, in Professional Negligence 238 \& n.142 (T. Roady \& W. Andersen eds. 1960).

${ }^{53}$ School districts might try to take advantage of this defense by requiring parents to sign a blanket waiver when their children enter kindergarten. It is far from certain, however, that such a waiver would be enforced. $C f$. Henningsen v. Bloomfield Motors, Inc., 32 N.J. 358, 386-403, 161 A.2d 69, 84-95 (1960).

${ }^{54}$ See text accompanying notes $219-40$ infra.

${ }^{35}$ See text accompanying notes $252-55$ infra.

${ }^{56}$ See, e.g., Defendants' Demurrer, supra note 47, at 17-18.

${ }^{57} \mathrm{See}$ Sax \& Hiestand, supra note 40, at 885-86.

${ }^{58}$ Professional Negligence, supra note 56, at 688-89.

${ }^{59}$ See Sax \& Hiestand, supra note 40 , at 875. 
Another argument against recognition of a cause of action for failure to learn because of teacher negligence or incompetence focuses on the administrative inconvenience which might be caused by a "flood of litigation" involving difficult problems of proof. Various authorities, however, have rejected this argument as a legitimate reason for denying liability when genuine and serious injuries have occurred. ${ }^{60}$ For example, Prosser writes, "It is the business of the law to remedy wrongs that deserve it, even at the expense of a 'flood of litigation' and it is a pitiful confession of incompetence on the part of any court of justice to deny relief on such grounds." 61 Moreover, problems of proof may be no more insurmountable than those involved in other kinds of lawsuits that are presently recognized, ${ }^{62}$ and, under the standards of negligence outlined in this Comment, ${ }^{63}$ a "flood of litigation" is unlikely.

In Doe v. San Francisco Unified School District, ${ }^{64}$ defendants argued that the "social importance" of free, universal public education should bar recovery for negligence. ${ }^{65}$ This argument has not prevented courts from holding school districts liable for physical injuries caused by teacher negligence, ${ }^{66}$ and the courts have generally declined to allow the importance of a public function to determine whether tort liability for negligent performance exists. ${ }^{67}$ Furthermore, if the costs of liability would not make public education economically infeasible (a factual question), there is no logical reason why the importance of public education should imply immunity.

In assessing the possible objections to recognizing this cause of action, the following observation of the Pennsylvania Supreme Court should be kept in mind:

Throughout the entire history of the law, legal Jeremiahs have moaned that if financial responsibility

${ }^{60}$ E.g., Battalla v. State, 10 N.Y.2d 237, 176 N.E.2d 729, 219 N.Y.S.2d 34 (1961); see W. PROSSER, supra note $25, \S 12$, at $51 \&$ n. 38 .

${ }^{61}$ W. ProsSER, supra note $25, \S 12$, at 51 .

${ }^{62}$ Text accompanying notes $219-55$ infra.

${ }^{63}$ Text accompanying notes 94-104 infra.

${ }^{64}$ No. 653-312 (Cal. Super. Ct., Sept. 6, 1974), appeal docketed, Civil No. 36851, 1st Dist. Ct. App., Apr. 28, 1975.

${ }^{65}$ Defendants' Demurrer, supra note 47, at 17.

${ }^{66}$ E.g., Bellman v. San Francisco High School Dist., 73 P.2d 596 (1937), aff'd on rehearing, 11 Cal.2d 576, 81 P.2d 894 (1938); Gardner v. State, 281 N.Y. 212, 22 N.E.2d 344 (1939).

${ }^{67}$ E.g., Johnson v. State, 69 Cal. 2d 782, 447 P.2d 352, 73 Cal. Rptr. 240 (1968). But see Lipman v. Brisbone Elementary School Dist., 55 Cal.2d 224, 359 P.2d 465, 11 Cal. Rptr. 97 (1961). 
were imposed in the accomplishment of certain enterprises, the ensuing litigation would be great, chaos would reign and civilization would stand still. It was argued that if railroads had to be responsible for their acts of negligence, no company could possibly run trains; if turnpike companies had to pay for harm done through negligence, no roads would be built; if municipalities were to be financially liable for damage done by their motor vehicles, their treasuries would be depleted. Nevertheless, liability has been imposed in accordance with elementary rules of justice and the moral code, and civilization in consequence, has not been bankrupted, nor have the courts been inundated with confusion. ${ }^{68}$

\section{Legal Theories}

No reported case has allowed public school students to recover for the loss of educational benefits because of teacher negligence or incompetence. The legal bases for such an action must be created by analogy from the law of malpractice and by a somewhat novel application of general principles of tort and contract law. Although any law student can raise objections to each of the legal theories that will be outlined, the analysis that follows may give a judge a legal formula with which to explain a policy-based plaintiff's decision. A plaintiff's verdict would in fact be a recognition of a new tort or contract cause of action, but the framing of the suit in familiar language would increase a court's receptiveness by making such a verdict appear less radical. ${ }^{69}$

In some jurisdictions, the plaintiff's task may be made much more difficult by continued adherence to the doctrine of governmental immunity from tort liability. ${ }^{70}$ The extent to which the doctrine would bar an action of this type varies greatly from jurisdiction to jurisdiction. Where the doctrine is applied most broadly, teachers, school officials, and school districts have been held immune from liability for students' injuries caused by the (1964).

${ }^{88}$ Doyle v. South Pittsburgh Water Co., 414 Pa. 199, 218-19, 199 A.2d 875, 884

${ }^{69} \mathrm{~W}$. Prosser, supra note $25, \S 6$, at 27.

${ }^{70}$ See Memorandum of Defendants at 3, McNeil v. Board of Educ., Civil No. L-17297-74 (N.J. Super. Ct., Essex County, filed Jan. 15, 1975), arguing that sovereign immunity should bar a former student's suit against a school board for the school system's alleged negligent failure to deal adequately with his reading and visual disability. See generally W. Prosser, supra note 25, §§ 131-32; Proehl, supra note 44, at 185-86, 202-04. 
negligent acts and omissions of teachers or school officials. ${ }^{71}$ Unquestionably, jurisdictions that bar liability for physical injuries would not allow liability for students' failure to learn. In some states, governmental immunity extends to school districts and officials but not to teachers. ${ }^{72}$ In other states, school districts are liable for injuries caused by the negligent acts and omissions of their teachers to the extent of the district's liability insurance coverage. ${ }^{73}$ In still other states, the doctrine of governmental immunity has been generally abrogated and exists only where immunity is specifically provided for by statute; ${ }^{74}$ in these states the teacher and the school district will generally be liable for injuries caused by the teacher's negligence. It suffices to point out that in at least some jurisdictions the doctrine does not absolutely bar actions against teachers, schools, and school districts to recover for injuries to students caused by teacher negligence, and that authorities have contended, as a matter of policy, that immunity doctrines should not insulate school districts, officials, and teachers from tort liability where liability insurance is available at non-crippling rates. ${ }^{75}$

\section{Tort Theories}

Three broad areas of tort law are relevant to a cause of action for failure to learn because of teacher incompetence: negligence, intentional tort, and misrepresentation (deceit and negligent misrepresentation).

\section{a. Negligence}

Section 328 A of the Restatement (Second) of Torts sets forth the essential elements of a negligence suit:

In an action for negligence, the plaintiff has the burden of proving

(a) facts which give rise to a legal duty on the part of the defendant to conform to the standard of conduct estab-

${ }^{71}$ E.g., Carroll v. Lucas, 39 Ohio Misc. 5, 313 N.E.2d 864 (C.P. 1974) (suit can be brought only with specific statutory authorization).

${ }_{72}$ E.g., Duncan v. Koustenis, 260 Md. 98, 271 A.2d 547 (1970).

${ }^{73}$ See Johnston v. Girvin, 61 Ill. App. 2d 47, 208 N.E.2d 894 (1965); Thomas v. Broadlands Community Consol. School Dist., 348 Ill. App. 567, 109 N.E.2d 636 (1952); Vendrell v. School Dist., 226 Ore. 263, 360 P.2d 282 (1961). But see Niedfelt v. Joint School Dist., 23 Wis. 2d 641, 127 N.W.2d 800 (1964).

${ }^{74}$ See, e.g., Spanel v. Mounds View School Dist., 264 Minn. 279, 118 N.W.2d 795 (1962).

${ }^{75}$ See, e.g., Duncan v. Koustenis, 26 Md. 98, 271 A.2d 547 (1970); Proehl, supra note 44 , at $202-03$. 
lished by law for the protection of the plaintiff, (b) failure of the defendant to conform to the standard of conduct,

(c) that such failure is a legal cause of the harm suffered by the plaintiff, and

(d) that the plaintiff has in fact suffered harm of a kind legally compensable by damages. ${ }^{76}$

Phrased differently, these elements are (1) a negligent act or omission, (2) a legally recognized harm, (3) cause in fact, (4) proximate cause, and (5) duty. ${ }^{77}$

A suit against a teacher to recover damages for a student's failure to learn because of teacher incompetence can easily be framed in the language of a typical negligence suit. ${ }^{78}$ At the very least, the plaintiff's case would involve establishing that the student's failure to learn is a "harm"79 cognizable in tort, that the teacher was negligent, ${ }^{80}$ that "but for" that negligence the student would not have suffered this harm, ${ }^{81}$ and that the teacher had a duty to teach the student non-negligently. ${ }^{82}$ Proximate cause is self-evidently present under most interpretations of the term. ${ }^{83}$ A student's failure to learn is clearly among the foreseeable risks of a teacher's poor classroom methods, thus satisfying one formulation of the term. ${ }^{84}$ Under the second major in-

76 Restatement (Second) of Torts $\$ 328$ A (1965).

${ }^{77}$ It is recognized that "duty," in this case duty to teach non-negligently, is a conclusory term. It is not clear whether it has a meaning independent of the concepts of negligence and proximate cause. Prosser writes:

The statement that there is or is not a duty begs the essential question-whether the plaintiff's interests are entitled to legal protection against the defendant's conduct. ... It is a shorthand statement of a conclusion, rather than an aid to analysis in itself. . . . [I]t should be recognized that "duty" is not sacrosanct in itself, but only an expression of the sum total of those considerations of policy which lead the law to say that the particular plaintiff is entitled to protection.

W. Prosser, supra note 25, § 53, at 325-26 (footnotes omitted). Nonetheless, this Comment will retain the term, since it is used by the judges whom the following arguments are intended to persuade.

${ }^{78}$ See Complaint, supra note 4 , at 6-8.

${ }^{79}$ Text accompanying notes $219-55$ infra.

80 Text accompanying notes 94-104 infra.

81 Text accompanying notes 219-36 infra.

82 Text accompanying notes 105-63 infra.

${ }^{83}$ The defendants in Doe v. San Francisco School Dist., No. 653-312 (Cal. Super. Ct., Sept. 6, 1974), appeal docketed, Civil No. 36851, 1st Dist. Ct. App., Apr. 28, 1975, conceded this point. See Defendants' Demurrer, supra note 47, at 14 .

${ }^{84}$ The area within which liability is imposed is that which is within the circle of reasonable foreseeability using the original point at which the negligent act was committed or became operative, and thence looking in every direction as the semi-diameters of the circle, and those injuries which from this point could or 
terpretation, proximate cause exists because a student's failure to learn is a direct consequence of the teacher's incompetent teaching. ${ }^{85}$ Unlike many novel tort claims, this type of suit does not involve injuries of a remote or unforeseeable character.

Assuming that the plaintiff is not barred by governmental immunity, ${ }^{86}$ the liability of the school district or municipality could be asserted under at least two theories. First, the doctrine of respondeat superior (either common law or statutory) may render the school district or municipality vicariously liable for the negligent acts and omissions of its teacher/employees. ${ }^{87}$ In some jurisdictions where the doctrine is not available, the teacher may have a statutory right to indemnification for losses incurred in a negligence judgment arising out of the teacher's employment. ${ }^{88}$ Second, the doctrine of respondeat superior may be invoked to render the school district liable for the negligence of its officials in hiring an incompetent teacher ${ }^{89}$-an act that was the cause in fact of the student's educational loss. ${ }^{90}$ Proximate cause would not be an obstacle, since the failure of the student to learn is clearly a direct and foreseeable consequence of the hiring of an incompetent teacher. Moreover, cases involving recovery for physical injuries caused by teacher negligence have shown that a court is more likely to find for the plaintiff on the liability issue if there is a legal basis for either the direct or derivative liability of the school district. ${ }^{91}$

Presumably, the usual tort defenses of contributory negligence and assumption of risk would be available. The methods of proof suggested in this Comment, however, may eliminate

should have been reasonably foreseen as something likely to happen, are within the field of liability, while those which, although foreseeable, were foreseeable only as remote possibilities, those only slightly probable, are beyond and not within the circle, -in all of which time, place and circumstance play their respective and important parts.

Mauney v. Gulf Ref. Co., 193 Miss. 421, 428-29, 9 So.2d 780, 781 (1942).

85 " 'Direct' consequences are those which follow in sequence from the effect of the defendant's act upon conditions existing and forces already in operation at the time, without the intervention of any external forces which come into active operation later."

W. Prosser, supra note 25, \& 43, at 263-64 (footnote omitted). See generally id. 251-70.

${ }^{86}$ See text accompanying notes 70-75 supra.

${ }^{87}$ E.g., Bellman v. San Francisco High School Dist., 73 P.2d 596 (1937), aff'd on rehearing, 11 Cal. 2d 576, 81 P.2d 894 (1938); Cherney v. Board of Educ., 31 App. Div. 2d 764, 297 N.Y.S.2d 668 (1969); CAL. Gov't Code § 815.2 (West 1966).

${ }^{88}$ See, e.g., N.Y. Educ. Law 3023 (McKinney 1970); Proehl, supra note 44, at 203.

${ }^{89}$ See Proehl, supra note 44, at 202.

${ }^{90}$ See, e.g., Engel v. Gosper, 71 N.J. Super. 573, 177 A.2d 595 (Super. Ct. 1962);

Kolar v. Union Free School Dist., 8 N.Y.S.2d 985 (Madison County Ct. 1939).

${ }^{91}$ Proehl, supra note 44, at 215-16. 
the factual basis for a contributory negligence defense.92 In some jurisdictions, the availability of both these defenses may be limited by precedent or statute making it impossible for a child below a certain age to be contributorily negligent or assume the risk. ${ }^{93}$

\section{(i) Negligence-The Standard}

Professional liability cases within and without the education area suggest the standard by which teachers' professional conduct should be judged:94 They "must have the skill and learning commonly possessed by members of the profession in good standing."95 In most states, this standard depends on where the defendant practices; usually he will be required to exercise only that degree of skill and training ordinarily possessed by members of the profession in his own or similar communities. ${ }^{96}$ When members of the profession disagree about which practices or procedures are correct, the professional will usually be judged by the school of thought to which he adheres, provided the school is "a recognized one with definite principles, and it must be the line of thought of at least a respectable minority of the profession." 97

Thus, a professional will be judged not by the "reasonable man" standard applied in ordinary negligence cases, but by comparison with his professional peers. In an ordinary negligence case, the jury may find that a defendant who conformed to the normal or average conduct of the community was nonetheless negligent. In a professional malpractice case, conformity to the norm or minimum of the professional community is by definition non-negligent, even though the jury may believe that the community norm or minimum is too low. ${ }^{98}$ This comparative standard, holding teachers to only a community norm or minimum, should keep the number of educational mal: practice suits within reasonable limits.

\footnotetext{
92 Text accompanying notes 219-55 infra. n.82.

${ }^{93}$ See W. Prosser, supra note $25, \S 32$, at $156-57, \S 65$, at $419 \&$ n. $31, \S 68$, at $447 \&$

94 See generally Professional Negligence (R. Roady \& W. Andersen eds. 1960).

$95 \mathrm{~W}$. Prosser, supra note $25, \S 32$, at 162 ; accord, Restatement (SeCOND) OF TORTS $\S 299$ A (1965); Professional Negligence, supra note 51, at 633.

${ }^{96} \mathrm{~W}$. Prosser, supra note $25, \S 32$, at 164.

${ }^{97}$ Id. 163; accord, ReSTATEMENT (SECOND) OF ToRTs $\$ 299 \mathrm{~A}$, comment $f$ at 75 (1965).

${ }^{98}$ But see Professional Negligence, supra note 51, at 639, arguing that the community standard has been limited and that a minimum level of competence may be required regardless of the level of the community.
} 
Indeed, this definition of negligence is probably underinclusive, because, especially in poor schools, the minimum level of teaching may be so low that many incompetent teachers will inevitably be deemed non-negligent. This standard therefore negates the possibility of using a negligence suit to achieve a general upgrading of ghetto education; the performance of the majority of ghetto schools and teachers will be, by definition, within the minimum standards of the professional community by which the teacher's performance is evaluated. It is not clear, however, that a negligence action is the appropriate legal base for a general attack upon low quality education. Applying the minimum standards of the professional community, a negligence action will at least provide a remedy for the very worst cases.

In suits against teachers to recover for physical injuries caused by inadequate teacher supervision, the conduct of the teacher has been judged by the usual tort standard of care-that of a "reasonable and prudent person acting under like circumstances."99 But in suits to recover for physical injuries to students caused by negligent instruction, the standard of negligence usually applied is similar to the general professional standard stated above. ${ }^{100}$ In a suit to recover for a student's failure to learn because of teacher negligence, the standard of acceptable instruction should be comparative, that is, the level of skill and learning of the minimally acceptable teacher in the same or similar communities. ${ }^{101}$ Unlike the supervision cases, this kind of suit may require a jury to evaluate the professional methods employed by the teacher, and the general professional standard is more suitable than the "reasonable man" standard for evaluating exercises of professional discretion and judgment. ${ }^{102}$ In addition, this standard will not inhibit the adoption of new teaching methods which have won acceptance by "a respectable minority of the profession."

Section 308 of the Restatement (Second) of Torts suggests the

99 Proehl, supra note 44, at 204-07.

${ }^{100}$ E.g., Gardner v. State, 281 N.Y. 212, 22 N.E.2d 344 (1939).

101 As Prosser notes, it is misleading to say that the appropriate standard is the level of skill and learning possessed by the average member of the profession: "only those in good professional standing are to be considered; and of these it is not the middle but the minimum common skill which is to be looked to." W. Prosser, supra note 25, § 32, at 163. It would be especially unwise to apply an "average" standard in a suit to recover for negligent instruction, because such a standard would define a large number of teachers as negligent. The standard of the minimally acceptable teacher is much more likely to receive judicial acceptance.

${ }^{102}$ See Professional Negligence, supra note 51, at 643-44. 
proper standard for determining the negligence of school officials who hire incompetent teachers:

It is negligence to permit a third person to . . . engage in an activity which is under the control of the actor, if the actor knows or should know that the person intends or is likely ... to conduct himself in the activity in such a manner as to create an unreasonable risk of harm to others."103

Under this standard, a school official would be liable for hiring a teacher he knew or should have known was incompetent or likely to teach negligently. Adoption of the "known or should have known" standard for school officials would likely have the beneficial effect of closer supervision of the classroom and the results produced in the classroom.

Proof of negligence, as will be explained, may involve expert testimony, evidence of failure to adhere to statutorily prescribed standards, and circumstantial evidence (inferences from unsatisfactory results). ${ }^{104}$

\section{(ii) Legal Precedents}

Various statutory, common law, and scholarly authorities support the contention that school districts and teachers should be held liable for the failure of students to learn because of the negligence of the teacher. These authorities affirm the existence of a duty of non-negligent instruction and the cognizability in tort of this type of harm.

Courts in many jurisdictions have held teachers and school districts liable for physical injuries to students caused by negligent conduct within the scope of the teacher's employment. ${ }^{105}$ Typical teacher negligence cases involve injuries arising from a lack of adequate teacher supervision. ${ }^{106}$ In these cases, the teacher has been held to the standard of a "reasonable and prudent person acting under like circumstances." ${ }^{107}$ Although under most circumstances a person does not have a duty to take affirmative action to protect others from a risk of harm which the person did not create, a special relationship between the parties, including the student-teacher relationship, has given rise to

${ }^{103}$ Restatement (Second) of Torts $\$ 308$ (1965).

${ }^{104}$ Text accompanying notes 219-55 infra; W. Prosser, supra note 25, §§ 37-40.

${ }^{105}$ See Proehl, supra note 44.

${ }^{106}$ See id. 204-07.

${ }^{107}$ Id. 201. 
such a duty. ${ }^{108}$ These cases support the general notion that a teacher may be liable to students for the foreseeable consequences of his negligent teaching. ${ }^{109}$

Another important line of cases has found liability where a student suffers physical injury because he was negligently instructed by a gym teacher. In Gardner $v$. State, ${ }^{110}$ for example, the state of New York was held liable for injuries sustained by a student attempting to perform a gymnastic stunt proximately caused by the failure of the gym teacher to follow customary methods of instruction. In a New Jersey case, the court upheld the legal sufficiency of the complaint in a suit against two science teachers and the school board to recover for a student's injuries and eventual death caused in part by the negligent failure of the teachers properly to instruct the student in the use of rockets. ${ }^{111}$ These cases, recognizing the legal duty of teachers to adhere to professionally acceptable (non-negligent) methods of instruction, ${ }^{112}$ are precedent for judicial evaluation of teaching quality and for the liability of teachers and their employers for the consequences of negligent instruction.

One might contend that this duty of non-negligent instruction exists only where the consequences of negligent instruction involve a risk of serious physical injury. Preventing failure of a student to learn, however, is arguably no less important than preventing physical injuries; ${ }^{113}$ moreover, the tort law does not recompense only physical injuries. ${ }^{114}$ Defamation, invasion of privacy, unfair competition, and legal malpractice are some areas of tort law where recovery is permitted for non-

${ }^{108}$ See W. Prosser, supra note $25, \S 56$, at 341-42, 348-49.

${ }^{109}$ Cf., e.g., Morgan v. County of Yuba, 230 Cal. App. 2d 938, 41 Cal. Rptr. 508 (Dist. Ct. App. 1964); Proehl, supra note 44, at 190 n.27.

${ }_{110} 281$ N.Y. 212, 22 N.E.2d 344 (1939); see Bellman v. San Francisco High School Dist., 73 P.2d 596 (1937), aff'd on rehearing, 11 Cal. 2d 576, 81 P.2d 894 (1938); Smith v. Consolidated School Dist., 408 S.W.2d 50 (Mo. 1966); Keesee v. Board of Educ., 37 Misc. 2d 414, 235 N.Y.S.2d 300 (Sup. C.t. 1962).

${ }^{111}$ Engel v. Gosper, 71 N.J. Super. 573, 177 A.2d 595 (Super. Ct. 1962). The bases for the school board's liability were the doctrine of respondeat superior and negligence in hiring unsuitable teachers. See also Klenzendorf v. Shasta Union High School Dist., 4 Cal. App. 2d 164, 40 P.2d 878 (Dist. Ct. App. 1935).

112 Curran, Professional Negligence-Some General Comments, in Professional Negligence 4 (T. Roady \& W. Andersen eds. 1960); accord, Lucas v. Hamm, 56 Cal. 2d 583, 643 P.2d 685, 15 Cal. Rptr. 821 (1961); Restatement (Second) of Torts $\$ 299$ A \& coment $c$ at 73-74 (1965). Another way to describe the "duty" to which the professional relationship gives rise is that conformity to the standards of the profession is an implicit term of the contract that arises between the professional and his client, patient, student, etc. See Professional Negligence, supra note 51, at 679; text accompanying note 183 infra.

${ }_{113}$ See text accompanying notes 33-40 supra.

${ }^{114}$ See generally Sax \& Hiestand, supra note 40, at 879-86. 
physical injuries. ${ }^{115}$ In the education context, courts have held school authorities liable for the intentional infliction of mental distress on a student. ${ }^{116}$

Both Prosser and the Restatement (Second) of Torts assert that when someone undertakes to render a service to another upon which the other relies, the actor assumes a duty to act nonnegligently and will be liable for harm that results from negligent performance. ${ }^{117}$ Prosser writes, "Where performance clearly has been begun, there is no doubt that there is a duty of care."118 Applied to education, this formulation suggests that once a teacher, school, and school district undertake to provide education, they assume a duty to educate non-negligently. This general principle of voluntary assumption of duty has been applied specifically to government undertakings in a variety of cases. Indian Towing Co. $v$. United States ${ }^{119}$ expresses the notion that the government will be liable for providing a service in a negligent manner, even though it was under no obligation to provide the service at all. This case held that when the Coast Guard exercised its discretion to operate a lighthouse, it was liable for damages resulting from the negligent failure to keep the light in good working order. In a California case, a county sheriff who made a gratuitous promise to warn the plaintiff of the release of a dangerous prisoner was held liable for injuries sustained by the plaintiff when the sheriff negligently failed to give the warning. ${ }^{120}$ Another California case held that the owner of a boat marina could bring an action against the state for damages resulting from the negligent preparation and release of weather and flood information. ${ }^{121}$ Similarly, when the state and its employees undertake to provide education, they assume a duty to do so non-negligently. ${ }^{122}$

\footnotetext{
115 See W. ProsSER, supra note $25, \S 1$, at $2-3$, \$\$ $111-17,130$.

${ }^{116}$ See, e.g., Johnson v. Sampson, 167 Minn. 203, 208 N.W. 814 (1926).

117 W. Prosser, supra note 25, § 56, at 343-48; Restatement (SEcond) of TorTs $\S$ $323 \&$ comment $e$ at 139 (1965).

${ }^{118} \mathrm{~W}$. Prosser, supra note $25, \S 56$, at 346 .

${ }^{119} 350$ U.S. 61 (1955); accord, Ingham v. Eastern Air Lines, Inc., 373 F.2d 227 (2d Cir.), cert, denied, 389 U.S. 931 (1967); Armiger v. United States, 339 F.2d 625 (Ct. Cl. 1964).

Indian Towing Co. also supports the contention that a plaintiff can recover for the denial of a benefit which he would have enjoyed but for the defendant's negligence. See text accompanying notes 127-36 infra. See also Sioux Tribe v. United States, $84 \mathrm{Ct}$. Cl. 16 (1936), cert. denied, 302 U.S. 740 (1937).

${ }^{120}$ Morgan v. County of Yuba, 230 Cal. App. 2d 938, 41 Cal. Rptr. 508 (Dist. Ct. App. 1964).

${ }_{121}$ Connelly v. State, 3 Cal. App. 3d 744, 84 Cal. Rptr. 257 (Dist. Ct. App. 1970).

122 The applicability of the cases cited in notes 113-16 supra may be qualified by the
} 
A plaintiff in an educational malpractice suit, however, will probably have to deal with a line of cases headed by $H$. R. Moch Co. v. Rensselaer Water Co. ${ }^{123}$ In Moch, a plaintiff was denied recovery against a water company, under contract with the city to provide water, which negligently failed to provide adequate water to extinguish a fire before it reached and destroyed the plaintiff's warehouse. The court held, inter alia, that the suit was not maintainable as an action for a common law tort. ${ }^{124} \mathrm{Al}$ though acknowledging that one who undertakes to act, even gratuitously, has a duty to act non-negligently, Judge Cardozo wrote,

If conduct has gone forward to such a stage that inaction would commonly result, not negatively merely in withholding a benefit, but positively or actively in working an injury, there exists a relation out of which arises a duty to go forward. ... The query always is whether the putative wrongdoer has advanced to such a point as to have launched a force or instrument of harm, or has stopped where inaction is at most a refusal to become an instrument for good. ${ }^{125}$

Cardozo characterized the failure to furnish an adequate supply of water as a denial of a benefit not the commission of a wrong. ${ }^{126}$

Moch could be troublesome for a plaintiff in an educational malpractice case; it has been argued that the failure of a student to learn because of teacher negligence or intentional misconduct is not an injury cognizable in tort-that it is not an injury at all, but rather the loss of an expectancy or failure to receive a benefit. ${ }^{127}$ In other kinds of cases, however, plaintiffs have recovered in tort for a variety of injuries which might be called lost expectancies or benefits. Legal malpractice cases, for example, have allowed plaintiffs to recover for benefits that they probably would have received under wills or from lawsuits but for the negligence of a lawyer. ${ }^{128}$ Plaintiffs have also been recompensed

governmental immunity doctrines of the particular jurisdiction. Text accompanying notes 70-75 supra.

123247 N.Y. 160, 159 N.E. 896 (1928); see Stang v. City of Mill Valley, 38 Cal. 2d 486, 240 P.2d 980 (1952); Reimann v. Monmouth Consol. Water Co., 9 N.J. 134, 87 A.2d 325 (1952).

124247 N.Y. at 167,159 N.E. at 898.

${ }^{125}$ Id. at $167-68,159$ N.E. at 898.

${ }^{126} I d$. at 169,159 N.E. at 899.

127 Defendants' Demurrer, supra note 47 , at 44-46.

${ }^{128}$ See, e.g., Lucas v. Hamm, 56 Cal. 2d 583, 364 P.2d 685, 15 Cal. Rptr. 821 (1961), 
for tortious interference with the expectation of business profits. ${ }^{129}$ The Restatement of Torts explains that "[w]here a person can prove that but for the tortious interference of another, he would have received a gift or a specific profit from a transaction, he is entitled to full damages for the loss which has thus been caused to him . . ." 130 Recovery usually has been denied, according to Prosser, in cases in which there was no sufficient degree of certainty that the anticipated benefit would have been received, and such cases do not deny the existence of tort liability. ${ }^{131}$ Courts have allowed recovery where the receipt of the benefits was not certain but only highly probable. Furthermore, it has been argued that plaintiffs should be allowed to recover for the lost chance of receiving a benefit, the degree of certainty being relevant only to valuation of the loss. ${ }^{132}$

Plaintiffs are also likely to recover for benefits denied because of the negligence of the person who seeks to bestow the benefit. For example, a rescuer who abandons or negligently performs a rescue is liable for resulting injury. ${ }^{133}$ Indeed, Prosser asserts that recovery for a denied benefit is highly probable even in the absence of evidence that the defendant's action deprived the plaintiff of assistance from someone else:

It seems very unlikely that any court will ever hold that one who has begun to pull a drowing man out of the river after he has caught hold of the rope is free, without good reason, to abandon the attempt, walk away and let him drown, merely because he was already in extremis before the effort was begun. ${ }^{134}$

The plaintiff's reliance and forbearance from seeking other services significantly strengthen an attempt to recover for

cert. denied, 368 U.S. 987 (1962); W. Prosser, supra note 25, § 130, at 949-54; Wade, supra note 52 , at 234 n.19.

${ }^{129} \mathrm{See}$ W. Prosser, supra note $25, \S 130$, at 950.

130 Restatement of Torts $\S 912$, comment $f$ at 584 (1939). See also Kely v. Price, 27 Cal. App. 3d 209, 103 Cal. Rptr. 531 (Dist. Ct. App. 1972). But see H.R. Moch Co. v. Rensselaer Water Co., 247 N.Y. 160, 159 N.E. 896 (1928).

${ }^{131} \mathrm{~W}$. Prosser, supra note $25, \S 130$, at 950-51.

${ }^{132}$ Id. 951 \& n.75. In Sioux Tribe v. United States, 84 Ct. Cl. 16 (1936), cert. denied, 302 U.S. 740 (1937), the court recognized that Indian children who had been denied educational benefits, which the Government should have provided under the terms of a treaty, had suffered a substantial loss. Yet the court denied recovery because the monetary value of the loss could not be calculated with sufficient certainty and exactitude. ${ }^{133}$ See W. Prosser, supra note 25, $\$ 56$, at 343-44; Restatement (Second) of Torts $\S 324$ A (1965).

134 W. Prosser, supra note $25, \S 56$, at 348 . 
the denial of benefits. ${ }^{135}$ Thus, it seems that the strongest case would be, for example, one in which the plaintiff's parents were considering sending him or her to a private school, but, after receiving assurances from the principal, school officials, and teachers that instruction in the public school would be competent, decided to send their child to the public school. As a result of negligent instruction, the student failed to attain as high an educational level as he would have attained in a non-negligently taught class. ${ }^{136}$ Characterizing the student's failure to learn as a lost benefit or expectation would not seem, at least under these circumstances, to preclude recovery.

Because the viability of the Moch distinction between denial of a benefit and commission of a wrong in tort actions is considerably undermined by the foregoing considerations and precedents, Moch is not followed in all jurisdictions. In 1964, the Supreme Court of Pennsylvania held that a complaint was sufficient in alleging that the plaintiff's house burned down because the water company, under contract with the city to provide water and maintain fire hydrants, had been negligent in maintaining the hydrant system. ${ }^{137}$ The Pennsylvania court wrote of Moch,

Once Justice Cardozo recognized that the defendant was guilty of a "negligent omission," he admitted that the defendant had committed a breach of duty since negligence is defined in law as a breach of duty. If there was no breach of duty on the part of the defendant, its conduct could be not characterized as a negligent omission, but would be merely an omission that did not amount to negligence. ${ }^{138}$

Even jurisdictions that follow Moch may not in fact be doing so in such a way as to impede school/teacher liability. In Reimann v. Monmouth Consolidated Water Co., ${ }^{139}$ the Supreme Court of New Jersey followed the Moch rule enunciating a policy basis, however, which suggests that the rule should not bar a suit for a student's failure to learn because of teacher negligence or incompetence. The court suggested that the availability of fire in-

135 Id. 343-48.

136 This also might be argued under a contract theory. See notes 181-207 infra \& accompanying text.

${ }^{137}$ Doyle v. South Pittsburgh Water Co., 414 Pa. 199, 199 A.2d 875 (1964). See also Evans v. Otis Elevator Co., 403 Pa. 13, 168 A.2d 573 (1961).

${ }^{138}$ Doyle v. South Pittsburgh Water Co., 414 Pa. 199, 214, 199 A.2d 875, 882 (1964).

1399 N.J. 134, 87 A.2d 325 (1952). 
surance supports placing the loss on the property owner rather than the water company. ${ }^{140}$ Students, however, cannot purchase insurance against their failure to learn. Indeed, the availability of liability insurance for teachers and school districts and the probable infrequency of educational malpractice suits undercut one of the primary policy reasons for denying liability in Moch-the fear of imposing a potentially limitless burden on suppliers of important public services. ${ }^{141}$

The duty arising from the control of the conduct of others provides another basis for the liability of school districts and officials for the educational harms caused by teachers who negligently or intentionally ${ }^{142}$ fail to meet minimum professional standards. According to the Restatement (Second) of Torts,

One who is required by law to take or who voluntarily takes the custody of another under circumstances such as to ... subject him to association with persons likely to harm him, is under a duty to exercise reasonable care so to control the conduct of third persons as to prevent them from intentionally harming the other or so conducting themselves as to create an unreasonable risk of harm to him, if the actor

(a) knows or has reason to know that he has the ability to control the conduct of the third persons, and

(b) knows or should know of the necessity and opportunity for exercising such control. ${ }^{143}$

These principles suggest that school officials should be liable if they subject students to instruction by teachers whom they knew or should have known were incompetent. ${ }^{144}$

Statutorily imposed obligations may also be used to establish the duty necessary for recovery on a negligence theory ${ }^{145}$ In fact, in cases where tort liability is based on a statutory violation, the courts may be more willing to allow non-traditional damage claims than in common law tort actions. For example, section 815.6 of the California Government Code provides:

${ }^{140} \mathrm{Id}$. at $139,87 \mathrm{~A} .2 \mathrm{~d}$ at 327.

141 H.R. Moch Co. v. Rensselaer Water Co., 247 N.Y. 160, 165-66, 159 N.E. 896, 897-98 (1928); see generally text accompanying notes 43-50, 65-68 supra.

142 Text accompanying notes 164-69 infra.

143 Restatement (Second) of Torts $\$ 320$ (1965); accord, W. Prosser, supra note 25, $\S 56$, at 349-50.

${ }^{144}$ As will be explained, these principles should also apply where a school official knew or should have known that a teacher would intentionally fail to teach according to minimum professional standards, e.g., because of racial bias. Notes 164-69 infra \& accompanying text.

145 See generally Sax \& Hiestand, supra note 40, at 914 \& n.180. 
Where a public entity is under a mandatory duty imposed by an enactment that is designed to protect against the risk of a particular kind of injury, the public entity is liable for an injury of that kind proximately caused by its failure to discharge the duty unless the public entity establishes that it exercised reasonable diligence to discharge the duty. ${ }^{146}$

The California supreme court ruled in Ramos $v$. County of Madera ${ }^{\mathbf{1 4 7}}$ that a county welfare department could be liable under section 815.6 for coercing minors to work under threat of losing the benefits of Aid to Families with Dependent Children, ${ }^{148}$ in violation of various regulations and statutes. In Bradford $v$. State ${ }^{\mathbf{1 4 9}}$ that court held that the state could be liable under section 815.6 for negligent failure to record the dismissal of criminal charges against an individual as required by statute.

The plaintiff in Doe v. San Francisco Unified School District ${ }^{150}$ invoked educational statutes to support the imposition of tort liability for negligent teaching under section 815.6. ${ }^{151}$ The various statutory provisions prescribe duties designed to protect students from the risk of not learning, and the plaintiff alleged that the defendants' failure to perform these duties resulted in the plaintiff's failure to learn. For example, plaintiff alleged violation of section 8573 of the California Education Code, which provides that "[n]o pupil shall receive a diploma of graduation from grade 12 who has not completed the course of study and met the standards of proficiency prescribed by the governing board."152 The defendants allegedly violated other statutory duties to keep parents accurately informed about the educational progress of their children, ${ }^{153}$ to provide a course of study designed to fit the needs of the pupils for whom the course of study was prescribed, ${ }^{154}$ to evaluate and revise the school district's educa-

${ }^{146}$ CAL. Gov't CODE $\$ 815.6$ (West 1966).

1474 Cal. 3d 685, 484 P.2d 93, 94 Cal. Rptr. 421 (1971). See also Elton v. County of Orange, 3 Cal. App. 3d 1053, 84 Cal. Rptr. 27 (Dist. Ct. App. 1970).

${ }^{148} 42$ U.S.C. $\$ \S 601-10$ (1970), as amended, (Supp. III, 1973).

14936 Cal. App. 3d 16, 111 Cal. Rptr. 852 (Dist. Ct. App. 1973).

${ }^{150}$ No. 653-312 (Cal. Super. Ct., Sept. 6, 1974), appeal docketed, Civil No. 36851, 1st

Dist. Ct. App., Apr. 28, 1975).

${ }^{151}$ Plaintiff's Memorandum, supra note 6, at 21-23.

21 n.12.

${ }^{152}$ CAL. Educ. Code $\S 8573$ (West 1975); Plaintiff's Memorandum, supra note 6, at

21 n.11.

${ }^{153}$ CAL. Educ. Code $\S 10759$ (West 1975); Plaintiff's Memorandum, supra note 6, at

${ }^{154}$ Cal. Educ. Code $\$ 8505$ (West 1975); Plaintiff's Memorandum, supra note 6, at

22 n.14. 
tional program ${ }^{155}$ and to examine, at least once a term, the management, needs, and conditions of the schools. ${ }^{156}$

The failure of students to learn is clearly the risk against which the above-described educational statutes were enacted to protect. Like the statutes involved in $\operatorname{Ramos}^{157}$ and Bradford, ${ }^{158}$ the educational statutes allegedly violated in Doe are designed to benefit a special segment of the community, school-age children, rather than the general public-a prerequisite to recovery under this theory. ${ }^{159}$ The requirements of section 815.6, therefore, would appear to have been met in Doe, subject, of course, to problems of proof. ${ }^{\mathbf{1 6 0}}$

The common law also recognizes the principle that negligent failure to perform a statutory duty gives rise to a cause of action in tort to recover for injuries caused by the negligence, if the person injured was a member of the class for whose benefit the statute was enacted and the injury was of a type which the statute was enacted to prevent. ${ }^{161}$ According to one court, "The disregard of the command of a statute is a wrongful act and a tort." 162

The Restatement (Second) of Torts maintains that although a court will not find that a statutory provision designed to secure a benefit to the general public creates a duty of reasonable care, an individual may maintain an action in tort on the basis of the statutory violation if he suffers a harm distinct from that suf-

${ }^{155}$ Cal. Educ. Code $\S 8002$ (West 1975); Plaintiff's Memorandum, supra note 6, at 22 n.13.

${ }^{156}$ Cal. Educ. Code $\S 1053$ (West 1975); Plaintiff's Memorandum, supra note 6, at 22 n.13.

The plaintiff in Doe also suggested that compulsory attendance statutes give rise to a "duty" by the school to provide minimally competent instruction, the violation of which gives rise to tort liability. E.g., CaL. Educ. CodE $\S 12154$ (West 1975); Mass. ANN. Laws ch. 76, 11 (Supp. 1975). See Plaintiff's Memorandum, supra note 6; $c f$. Serna v. Portales Municipal Schools, 351 F. Supp. 1279 (D.N.M. 1972), aff'd, 499 F.2d 1147 (10th Cir. 1974); Mills v. Board of Education, 348 F. Supp. 866 (D.D.C. 1972). The plaintiff further suggested that if there is no such "duty," the compulsory education statutes may be unconstitutional. Plaintiff's Memorandum, supra note 6, at 17; $f f$. Wyatt v. Stickney, 325 F. Supp. 781 (M.D. Ala. 1971). Other arguments made by plaintiff based on a constitutional right (state and federal) to education are beyond the scope of this Comment. Plaintiff's Memorandum, supra note 6, at 37-39; see Ratner, supra note 12.

1574 Cal. 3d 685, 484 P.2d 93, 94 Cal. Rptr. 421 (1971).

15836 Cal. App. 3d 16, 111 Cal. Rptr. 852 (Dist. Ct. App. 1973).

${ }^{159}$ See Stang v. City of Mill Valley, 38 Cal. 2d 486, 240 P.2d 980 (1952);

Restatement (SECOND) OF ToRTs $\S \S 286,288$, comment $c$ at 31 (1965).

${ }^{160}$ Text accompanying notes 219-55 infra.

${ }^{161}$ See, e.g., Routh v. Quinn, 20 Cal. 2d 488, 127 P.2d 1 (1942); Restatement

(SECOND) OF ToRts $\$ \$ 288 \mathrm{~B}, 286$.

${ }^{162}$ Kardon v. National Gypsum Co., 69 F. Supp. 512, 513 (E.D. Pa. 1946). 
fered by the rest of the community. ${ }^{163}$ The harm suffered by the students of an incompetent teacher is obviously of a different type from that suffered by the general community.

\section{b. Intentional Tort}

Under some circumstances, a student may be able to recover for failure to learn under an intentional tort theory, akin to intentional infliction of mental distress. ${ }^{164}$ Suppose, for example, that a high school English teacher, with preconceptions about the limited educability of his ghetto students, decides not to teach them literature but instead distributes comic books or third grade reading matter. Suppose that a high school science teacher with a similar appraisal of his students decides that there is no reason for them to learn chemistry and spends the term trying to inculcate passivity, deference, and good behavior. Depending on the teacher's state of mind, this behavior might be characterized as an intentional tort. ${ }^{165}$ Although intentional denial of an educational benefit is beyond the present boundaries of tort law, it is a harm at least as demonstrable and as deserving of redress as intentionally inflicted mental distress. Because the law of intentional torts is probably more elastic in the recognition of new kinds of injuries than is the law of negligence, ${ }^{166}$ an intentional tort theory provides a promising legal framework for a suit of this type, where the facts permit its use.

A plaintiff also might present a case of this type as an intentional infliction of mental distress. If the claim is, for example, that the teacher intentionally humiliated a student, the case is not especially difficult ${ }^{\mathbf{1 6 7}}$ but is clearly different from the kind of suits contemplated by this Comment. If it is argued that mental distress resulted from the intentional denial of educational

163 Restatement (Second) of Torts § 288, comment $c$ at 31 (1965); see Stang v. City of Mill Valley, 38 Cal. 2d 486, 240 P.2d 980 (1952); Restatement (SECOND) OF ToRTs $\$ \$$ 286,288 (1965).

164 See Johnson v. Sampson, 167 Minn. 203, 208 N.W. 814 (1926); W. Prosser, supra note $25, \S 12$, at $49-62$.

165 The intent with which tort liability is concerned is not necessarily a hostile intent, or a desire to do any harm. Rather it is an intent to bring about a result which will invade the interests of another in a way that the law will not sanction. The defendant may be liable although he has meant nothing more than a good-natured practical joke, or has honestly believed that he would not injure the plaintiff, or even where he was seeking the plaintiff's own good.

W. ProsSER, supra note 25, § 12, at 31 .

166 "In this respect, the law is clearly in a process of growth, the ultimate limits of which cannot as yet be determined." Id. 50 .

${ }^{167}$ See Johnson v. Sampson, 167 Minn. 203, 208 N.W. 814 (1926). 
benefits, ${ }^{168}$ it is unclear whether this claim puts the case within the existing case law. Representing the denial of educational benefits as not merely analogous to but in itself constituting the intentional infliction of mental distress, however, may make the argument seem less radical and more familiar and persuasive to a court.

\section{c. Misrepresentation}

In some situations, a student-plaintiff may be able to seek recovery on theories of negligent or intentional misrepresentation. Assume that a teacher issues a satisfactory progress report about a student who the teacher knows or should know is not progressing satisfactorily. (Standardized test scores, for example, indicate that the student is reading far below grade level.) The student's parents seek confirmation of the report from the teacher, explaining that they will obtain remedial instruction if their child is not making satisfactory progress. The teacher, to dissuade the parents from speaking to his or her superior regarding such instruction, reassures them of the student's satisfactory performance; as a result of the teacher's reports, the student never receives remedial instruction.

This factual situation seems to satisfy Prosser's enumeration of the elements of a cause of action in deceit:

1. A false representation made by the defendant. ...

2. Knowledge or belief on the part of the defendant that the representation is false-or, what is regarded as equivalent, that he has not a sufficient basis of information to make it. ...

3. An intention to induce the plaintiff to act or to refrain from action in reliance upon the misrepresentation.

4. Justifiable reliance upon the representation on the part of the plaintiff, in taking action or refraining from it.

5. Damage to the plaintiff, resulting from such reliance. ${ }^{169}$

In some jurisdictions, a negligent misrepresentation also may give rise to tort liability. A representation made without

${ }^{168}$ Complaint, supra note 4 , at 8-9.

${ }^{169}$ W. Prosser, supra note 25, at 685-86 (footnotes omitted). Cf. Connelly v. State, 3 Cal. App. 3d 744, 84 Cal. Rptr. 257 (Dist. Ct. App. 1970). 
knowledge of its falsehood is negligent if the defendant did not take reasonable care to ascertain its truth. ${ }^{170}$ The necessary duty of reasonable care in ascertaining the $\operatorname{truth}^{171}$ can easily be found in the student-teacher relationship ${ }^{172}$ or in statutes requiring the teacher to give accurate evaluations of students' achievement. ${ }^{173}$ The teacher's knowledge that the parent will reasonably rely on the representation should also be sufficient to establish a duty of reasonable care. ${ }^{174}$ The requirement that the plaintiff's reliance and his actions based on that reliance be reasonable seem easily satisfied in this context. ${ }^{175}$

Misrepresentations of opinion are generally not a basis for relief, ${ }^{\mathbf{1 7 6}}$ and it is debatable whether a student's progress report is a statement of fact or opinion. Even assuming that it is merely a teacher's opinion, however, there are exceptions to the general rule where special circumstances make it reasonable for the plaintiff to accept and act in reliance upon the statement: where reliance is justifiable, where the opinion implies that the defendant knows of no facts which would preclude the opinion and knows facts which justify it, or where the defendant holds himself out as having special knowledge of the matter which is not available to the plaintiff. ${ }^{177}$ A student's progress report written by a teacher seems to fit all these exceptions.

Other situations which could give rise to a misrepresentation action include the following:

(1) Parents trying to decide whether to send their child to public or private school ask public school officials about the quality of the public schools. The school officials, who know or should know of the poor quality of the public schools, assure the parents that their school offers high quality education. The student, previously an outstanding performer, falls to a low level of achievement, as measured by standardized tests. ${ }^{178}$ In the case of a similar representation by a private school, a claim of deceit or negligent misrepresentation might be raised to obtain rescission

${ }^{170}$ W. Prosser, supra note 25, § 107, at 704 .

171 Id. 706.

172 "[W] $[$ here the representation, although itself gratuitous, is made in the course of the defendant's business or professional relations, the duty is usually found." Id.

${ }^{173}$ See, e.g., CAL. Educ. Code $\$ 10759$ (Supp. 1975).

174 W. ProssER, supra note $25, \S 107$, at 707 .

${ }^{175}$ See id. $\$ 108$, at 714-20.

${ }^{176}$ Id. $\S 109$, at 721 .

${ }^{177}$ Id. 726-27.

${ }^{178}$ See text accompanying notes 219-55 infra. 
of a contract or used as a defense in a suit by the school for tuition. ${ }^{179}$

(2) Teachers and school officials who know or should know of the student's inferior academic ability urge him to switch from the vocational to the academic course of study, misrepresenting his abilities to him in order to correct an imbalance between the two programs. The student switches, performs poorly in the academic program, and leaves school without vocational skills and unqualified for a college education.

(3) The teacher negligently or intentionally misrepresents a student's progress, as a result of which the student is held back a year. The student sues for loss of a year's income. ${ }^{180}$

\section{Contract Theories}

The law of contracts provides several lines of argument which might support a suit for failure to learn because of teacher negligence or incompetence. ${ }^{181}$ First, it might be argued that there are implied contracts between the teacher and the student and between the school district and the student. An implied term of the contracts is that the student will be given non-negligent instruction. ${ }^{182}$ The consideration for this promise is that the stuinfra.

${ }^{179}$ See W. Prosser, supra note $25, \S 105$, at 687-89; text accompanying notes $256-63$

${ }^{180}$ See W. Prosser, supra note 25, $\$ 106$, at 694-95. Misrepresentation is available to people other than the student and his parents. Assume that the school issues a diploma and recommendation, representing (expressly or impliedly) that the student possesses certain minimum educational skills. An employer relies on these representations and hires the student, who is illiterate and consequently untrainable. The student makes serious reading or counting errors which result in a loss to the employer. The employer might have a cause of action for misrepresentation. See id. For a discussion of the usefulness of misrepresentation theories in the private school context, see notes 256-63 infra \& accompanying text.

${ }_{181}$ Since American courts have extended tort liability for misfeasance to virtually every type of contract where defective performance may injure the promisee, a plaintiff may have the option to sue in tort, contract, or both. W. Prosser, supra note $25, \S 92$, at 617 nn.47-56 \& 65; see Wade, supra note 52, at $219 \&$ n. 13.

182 See Lucas v. Hamm, 56 Cal. 2d 583, 364 P.2d 685, 15 Cal. Rptr. 821 (1961), cert. denied, 368 U.S. 987 (1962), in which the court found that by accepting employment to give legal advice or services, a lawyer impliedly agrees to use such skill, prudence, and diligence as lawyers of ordinary skill and capacity commonly possess and exercise in the performance of professional tasks they undertake; Wade, supra note 52, at 218-19 n.11; Professional Negligence, supra note 51, at 679. See also Arthur Murray, Inc. v. Parris, 243 Ark. 441, 420 S.W.2d 518 (1967); Stad v. Grace Downs Model \& Air Career School, 65 Misc. 2d 1095, 319 N.Y.S.2d 918 (Queens County Civ. Ct. 1971). It should be made clear that this is something distinct from a negligence action in tort, although Prosser points out that there will be liability in tort for misperformance of a contract whenever there would have been liability for gratuitous performance without a contract. W. Prosser, supra note 25,892 , at 617 . The notion of non-negligent instruction is borrowed from the tort law to "measure" the promise to teach. It is arguable that by holding himself out as a 
dent, in reliance on this implied promise, forbears seeking education elsewhere and attends school although, at least in the case of secondary school students, he could drop out. ${ }^{183}$ An alternative formulation could be based on the doctrine of promissory estoppel. ${ }^{184}$ It could be argued that the teacher's implied promise to teach non-negligently or the school district's implied promise to provide non-negligent teachers was made binding by the student's detrimental reliance on the promise.

A problem with this contractual theory is the requirement in some jurisdictions that consideration be "bargained for." 185 Even in such jurisdictions, however, this contract might stand since the student's attendance in reliance upon the implied promise of non-negligent instruction was within the contemplation of the parties. A second problem is the contention that the student's attendance cannot be consideration, because it is required by law ${ }^{\mathbf{1 8 6}}$ and the student could not have refused to attend. ${ }^{187}$ Furthermore, compulsory attendance does not apply to students above a certain age; finding consideration in attendance by these students would not be subject to the above-stated objection. Even for students within the age of compulsory attendance, forbearance from seeking private instruction could be consideration for the promise of non-negligent instruction or, alternatively, might bring into operation the doctrine of promissory estoppel. ${ }^{188}$ Of course a defendant could require a showing that plaintiff would or might have sought private education if not for the promise of non-negligent teaching. This possible requirement might have the anomalous effect of making this contract theory available only to relatively wealthy students who could have afforded private education.

Although the theory of contractual agreements between student and school district and between student and teacher is most plausible in the private school context where both the

teacher in certain school districts a teacher is implicitly promising a higher level of competence than mere non-negligence. Although this approach is distinct from a negligence theory of tort liability, the procedures outlined in this Comment for proving negligence, causation, and damages seem applicable to the various contract actions suggested in this section.

${ }^{183}$ See J. Calamari \& J. Perillo, The Law of Contracts $\$ \$ 53-56,61$ (1970).

${ }^{184}$ See id. §§ 99-111.

${ }^{185} I d$. $\S 53$, at 105 .

${ }^{186}$ E.g., Mass. ANn. Laws ch. 76, §§ 1,2 (Supp. 1975).

${ }^{187}$ See J. Calamari \& J. Perillo, supra note $183, \S 60$.

${ }^{188}$ If students are not given competent instruction compulsory attendance may also be a deprivation of liberty without due process of law in violation of the fourteenth amendment. See Ratner, supra note 12 , at 18. 
promise and the consideration are easily identifiable, ${ }^{189}$ it is applicable in the public school context in certain situations. For example, assume that a family moves to a new town and the parents tell the public school principal that they are trying to decide whether to send their child to public or to private school. Perhaps they express particular concern about the reading program. After the principal and teachers assure the parents of the competence of the reading teachers, the parents decide to send their child to public school, where he is negligently taught. The contract approach would also be applicable where a high school student is negligently taught after being dissuaded, by his principal and teachers, from dropping out of school to get a job because he believes his teachers are incompetent. ${ }^{190}$

There is another contract theory upon which a public school student might base a suit for his failure to learn because of teacher negligence. The plaintiff could argue that an implied term of the contract between the teacher and the school district is that the teacher will teach non-negligently. ${ }^{191}$ The student, as a third party beneficiary of the contract, should have a right to recover for its breach by the teacher. ${ }^{192}$

Professors Calamari and Perillo assert that the test of whether a beneficiary of a contract has a right to enforce it is whether there is an "intent to benefit" the third party. ${ }^{193}$ While a minority of courts have held that both parties must intend to benefit the third party, the majority believe that the promisee's intention is more important. ${ }^{194}$ The Restatement (Second) of Contracts concludes that "intent to benefit" is ascertained by whether " $[t]$ he beneficiary would be reasonable in relying on the promise as manifesting an intention to confer a right on him."195 Many

189 See Arthur Murray, Inc. v. Parris, 243 Ark. 441, 420 S.W.2d 518 (1967). See also Stad v. Grace Downs Model \& Air Career School, 65 Misc. 2d 1095, 319 N.Y.S.2d 918 (Queens County Civ. Ct. 1971).

${ }^{190}$ The question of damages is discussed at text accompanying notes 19-31 supra.

${ }^{191}$ See Lucas v. Hamm, 56 Cal. 2d 583, 364 P.2d 685, 15 Cal. Rptr. 821 (1961), cert. denied, 368 U.S. 987 (1962); Professional Negligence, supra note 51; notes 94-104 supra \& accompanying text.

${ }^{192}$ See, e.g., Lucas v. Hamm, 56 Cal. 2d 583, 364 P.2d 685, 15 Cal. Rptr. 821 (1961), cert. denied, 368 U.S. 987 (1962); Gorrell v. Greensboro Water-Supply Co., 124 N.C. 328, 32 S.E. 720 (1899); J. Calamari \& J. Perillo, supra note 183, § 243; $c f$. Lemon v. Bossier Parish School Bd., 240 F. Supp. 709 (W.D. La. 1965), aff'd, 370 F.2d 847 (5th Cir.), cert. denied, 388 U.S. 911 (1967); Randall v. Sumter School Dist., 232 F. Supp. 786 (E.D.S.C. 1964), modified, 241 F. Supp. 787 (E.D.S.C. 1965). But see H.R. Moch Co. v. Rensselaer Water Co., 247 N.Y. 160, 159 N.E. 896 (1928).

${ }^{193} \mathrm{~J}$. Calamari \& J. Perillo, supta note 183 , § 244, at 380-81.

${ }^{194} I d .380$.

195 Restatement (Second) of Contracts $\S 133$, comment $d$ at 288 (Tent. Drafts 
cases have held that if performance runs to the third party, he will ordinarily be treated as an intended beneficiary with enforceable rights. ${ }^{196}$ Under any of these approaches, a student is at least arguably a third party beneficiary with a right to enforce ${ }^{197}$ the teacher's implied (or express) promise to the school district to teach non-negligently. ${ }^{198}$

In some jurisdictions, the third-party beneficiary theory is hampered by the doctrine that where a municipal government contracts with a contractor for the benefit of the municipality's inhabitants, individual inhabitants generally do not have a right to enforce the contract. ${ }^{199}$ Yet there are exceptions to this rule. If a contractor agrees to perform services which the municipality is under a legal duty to provide to specified individual members

Nos. 1-7, 1973); see J. Calamari \& J. Perillo, supra note 183 , § 244, at 381 . In some states the rights of third party beneficiaries are set forth in statutes.

$196 \mathrm{~J}$. Calamari \& J. Perillo, supra note 183, \& 244, at 381.

197 In Lucas v. Hamm, 56 Cal. 2d 583, 364 P.2d 685, 15 Cal. Rptr. 821 (1961), cert. denied, 368 U.S. 987 (1962), the court recognized that it is essentially a matter of policy whether defendant (breaching promisor) will be liable to third party beneficiaries.

[T] he determination whether in a specific case the defendant will be held liable to a third person not in privity is a matter of policy and involves the balancing of various factors, among which are the extent to which the transaction was intended to affect the plaintiff, the foreseeability of harm to him, the degree of certainty that the plaintiff suffered injury, the closeness of the connection between the defendant's conduct and the injury, and the policy of preventing future harm.

Id. at 588, 364 P.2d at 687, 15 Cal. Rptr. at 823. The court also emphasized that the plaintiff would be able to recover as a third party beneficiary under a contract theory, because the main purpose of the contract was to benefit third parties, and it was the clear intent of the promisee that the contract benefit these third parties. Id. at 589-90, 364 P.2d at 688,15 Cal. Rptr. at 824.

${ }^{198}$ If the school district is not vicariously liable, which it might not be since the teacher's liability would be for breach of contract rather than for tortious acts or omissions, the liability would rest upon the teacher alone. This might jeopardize both the legal and practical chances of recovering substantial monetary damages at the present time. Text accompanying note 91 supra. If, however, a precedent of liability were set, it is likely that teachers would soon carry malpractice insurance as a matter of course, see notes 44-46 supra \& accompanying text, and recovery of money damages for remedial instruction might become a practical possibility. Even though money recovery seems improbable, the student might, under some circumstances, demand specific performance of the promise of non-negligent teaching. See Lemon v. Bossier Parish School Bd., 240 F. Supp. 709 (W.D. La. 1965), aff'd, 370 F.2d 847 (5th Cir.), cert. denied, 388 U.S. 911 (1967); Randall v. Sumter School Dist., 232 F. Supp. 786 (E.D.S.C. 1964), modified, 241 F. Supp. 787 (E.D.S.C. 1965). For example, if the negligence of the teacher consisted of failure to follow accepted teaching techniques, the court might order the teacher to adopt accepted methods, e.g., order a reading teacher who failed to give out books to do so. Also, the student might be able to enforce a contractual term allowing the school board to dismiss the teacher "for cause."

${ }^{199}$ See H.R. Moch Co. v. Rensselaer Water Co., 247 N.Y. 160, 159 N.E. 896 (1928); J. Calamari \& J. Perillo, supra note 183, § 247, at 387. But see, e.g., Gorrell v. Greensboro Water-Supply Co., 124 N.C. 328,32 S.E. 720 (1899). 
of the public, a contractor's improper performance of the contract resulting in injury to these individuals will give them a cause of action for breach. ${ }^{200}$ It has also been held that contracts into which a governmental unit enters, not just to protect the public from harm, but to secure advantages to the public, create rights enforceable by members of the public. ${ }^{201}$ Because students are an identifiable class of persons for whose benefit the teacher's promise of non-negligent instruction is ostensibly made, and because the municipality is probably under a legal duty to provide education the students should fall within the exceptions to the non-enforcement rule.

A contract approach in a suit for failure to learn because of teacher negligence or incompetence may have several advantages over a tort approach. First, governmental immunities, which may bar recovery in tort, might not preclude a successful contract action. ${ }^{202}$ Second, courts may be more willing to allow recovery for loss of an expectancy or benefit in contract than in tort. $^{203}$ In Doe v. San Francisco Unified School District, ${ }^{204}$ the defendant suggested that recovery for the injuries alleged in that suit would be possible in a contract action, although he denied the existence of a contract upon which to base an action. ${ }^{205}$ Third, defenses such as contributory negligence or assumption of risk may bar recovery in tort but not in contract. Finally, actions in tort and actions in contract may be governed by different statutes of limitations, the statutes generally being shorter for tort actions. ${ }^{206}$

On the other hand, recovery under some theories of contract damages may be limited to the damages tacitly agreed upon by the parties-perhaps payment for remedial instruction to confer the benefit denied by the teacher-while recovery in tort may extend to a wider range of damages, for example, loss of future income. ${ }^{207}$ Furthermore, the tort law is more flexible and more hospitable to novel lawsuits than the law of contracts. Ul-

200 J. Calamari \& J. Perillo, supra note 183 , § 247, at 388.

201 Id. 389 \& nn.64-68.

${ }^{202}$ W. Prosser, supra note $25, \S 92$, at 619 ; see notes $70-75$ supra \& accompanying text.

${ }^{203}$ See W. Prosser, supra note $25, \S 92$, at 619. But see Lucas v. Hamm, 56 Cal. 2d 583, 364 P.2d 685, 15 Cal. Rptr. 821 (1961), cert. denied, 368 U.S. 987 (1962); W. Prosser, supra note 24, § 93, at 623 .

${ }^{204}$ No. 653-312 (Cal. Super. Ct., Sept. 6, 1974), appeal docketed, Civil No. 36851, 1st Dist. Ct. App., Apr. 28, 1975.

205 Defendants' Demurrer, supra note 47 , at 4 .

${ }^{206}$ W. ProsSER, supra note $25, \S 92$, at 618 .

${ }^{207}$ Id. 619. 
timately, the desirability of proceeding in tort, contract, or both, will depend on the circumstances of the particular case.

\section{Mandamus}

If the court refuses to recognize a tort or contract theory, a plaintiff might seek relief by petition for mandamus. If this approach is available at all, however, it could only be used in a very limited number of situations.

A writ of mandamus is a court order compelling a person to perfom a duty imposed on him by law. ${ }^{208}$ Mandamus is most often used to compel an official to take action of a nondiscretionary or "ministerial" nature. ${ }^{209}$ Although it can also be used to compel an official to exercise his discretion, ${ }^{210}$ it will not compel him to exercise that discretion in a particular manner, unless the official's prior discretionary action was arbitrary or unreasonable. ${ }^{211}$ Other requirements for use of mandamus (depending on the jurisdiction) are a clear legal right in the plaintiff ${ }^{212}$ or a clearly prescribed official duty in the performance of which the plaintiff has an interest, ${ }^{213}$ and the inadequacy of other legal remedies. ${ }^{214}$

In education cases, mandamus has been used to compel school officials to perform ministerial duties ${ }^{215}$ and exercise discretion. ${ }^{216}$ In some cases courts have reviewed discretionary actions of school officials under an "arbitrary and unreasonable" standard. 217

Suppose that a state statute clearly directs school officials to hire teachers with certain qualifications, and an official hires a teacher without those qualifications. Mandamus might be used to enjoin the official from rehiring that teacher. The remedy might also be available to halt the practice of graduating students who fail to obtain the minimum level of reading competence required

${ }^{208}$ See, e.g., Leonard v. School Comm., 349 Mass. 704, 212 N.E.2d 468 (1965).

${ }^{209}$ See, e.g., Shirey v. City Bd. of Educ., 266 Ala. 185, 94 So. 2d 758 (1957).

${ }^{210}$ E.g., Martin v. Garnet Valley School Dist., 441 Pa. 502, 272 A.2d 913 (1971);

State ex rel. Knudsen v. Board of Educ., 43 Wis. 2d 58, 168 N.W.2d 295 (1969).

${ }^{211}$ E.g., Gustafson v. Wittersfield Twp. High School, 319 Ill. App. 255, 49 N.E.2d

311 (1943); Martin v. Garnet Valley School Dist., 441 Pa. 502, 272 A.2d 913 (1971).

212 See, e.g., Martin v. Garnet Valley School Dist., 441 Pa. 502, 272 A.2d 913 (1971);

Wenders v. White Mills Indep. School Dist., 171 Pa. Super. 39, 90 A.2d 318 (1952).

${ }^{213}$ See, e.g., Leonard v. School Comm., 349 Mass. 704, 212 N.E.2d 468 (1965).

${ }^{214}$ E.g., Shirey v. City Bd. of Educ., 266 Ala. 185, 94 So. $2 d 758$ (1957).

215 Id.

${ }^{216}$ See, e.g., cases cited note 210 supra.

${ }^{217}$ E.g., State ex rel. Baker v. Stevenson, 27 Ohio Op. 2d 223, 189 N.E.2d 181 (C.P.

1962); Leonard v. School Comm., 349 Mass. 704, 212 N.E.2d 468 (1965). 
by statute for graduation. ${ }^{218}$

Notwithstanding the usefulness of mandamus in these limited cases, it is unlikely that a court in a mandamus action would order dismissal of a teacher deemed competent by school officials, or would compel officials to take a particular remedial action. Nor would mandamus provide a route for requiring compensation for lost earnings. The limited extent to which the remedy can be used to challenge official policies and decisions of a discretionary character severely impairs its efficacy; it does not serve the function of the tort or contract cause of action.

\section{Problems of Proof}

\section{Proof of Causation of Harm}

The first question likely to be provoked by the suggestion of a cause of action for the failure of students to learn because of teacher incompetence is that of proof: How can a plaintiff prove that a teacher's negligence caused his failure to learn? A method of proof that relies on inferences drawn from circumstantial evidence is essential in this type of case. ${ }^{219}$ If an individual student alleges that his failure to learn was due to the incompetence or negligence of his teacher[s], it perhaps seems impossible to prove that the substandard result was not the consequence of the student's own lack of intelligence, aptitude, diligence, attitude, ambition, or general educability. ${ }^{220}$ This obstacle to plaintiff's proof of causation can be avoided if the plaintiff undertakes a comparative method of proof.

\section{a. The Comparative Method}

Under this method of proof, the plaintiff establishes causation by proving that a class of which he is a member performed significantly worse than did classes identical in all essential re-

${ }^{218}$ See, e.g., CAL. Educ. Code $\$$ 8573-75 (West 1975).

${ }^{219}$ See Lubell v. Nyquist, 31 App. Div. 2d 569, 294 N.Y.S.2d 961 (1968), appeal denied, 23 N.Y. 645, 298 N.Y.S.2d 1027 (1969); Restatement (SECoND) OF ToRTs § 328 D $\&$ comment $b$ at 157-58 (1965); $c f$. Fowler v. Seaton, 61 Cal. 2d 681, 394 P.2d 697, 39 Cal. Rptr. 881 (1964). But see Wade, supra note 52, at 228, stating, "There is no indication of application of ... res ipsa loquitur to attorney-negligence cases."

${ }^{220}$ Of course, a student with a high intelligence, documented diligence, and a record of achievement in other courses might be able to establish that his failure to achieve high standardized test scores in a subject was due to the negligence or incompetence of his teacher, since he could eliminate the other possible causes. For less "ideal" students, however, this approach would not be available. 
spects except that they were not taught by the defendant teacher. The class of which the plaintiff is a member ("plaintiff class") can consist of the students of a particular teacher in one year or over a number of years, or students who have completed an entire reading or math program in one year or over a number of years. The causal effect of a teacher on the educational achievement of his or her students can be isolated by comparing the performance of the plaintiff class with the performances, in the same subject, of students in the same or similar communities, in schools of the same socio-economic composition, similar size and per-student funding, in classes of similar size, with the same IQ groupings, or other characteristics identified by experts as determinants of educational success (comparison classes). ${ }^{221}$ By holding constant these factors, which could have determined the educational success of the student class, the effect of the teacher on student performance can be proven. ${ }^{222}$ The plaintiff would introduce expert testimony that the comparisons have, in fact, held constant all the factors, other than teacher quality, relevant to the performance of a class of students. ${ }^{223}$ Class performance could be measured by the average of the differences between scores on achievement tests taken by each student upon entering and leaving the teacher's class. ${ }^{224}$

Suppose that at the beginning of the school year students of teacher $A$ read, on the average, at the third-grade level. At the end of the school year they read on the fourth-grade level. Students of teacher $B$, who have the same "essential characteristics" (enumerated above) as the students of teacher $A$, begin the year

221 See McCormick's Handbook of the LaW of Evidence § 202, at 485 (2d ed. E. Cleary 1972) [hereinafter cited as MCCormICK]; C. JENCKs, supra note 11.

${ }^{222}$ See MCCoRmick, supra note 221, § 202 at 485; C. JENCKs, supra note 11. Various authorities support the use of circumstantial evidence to prove both cause in fact and negligence. In Lubell v. Nyquist, 31 App. Div. 2d 569, 294 N.Y.S. 2d 961 (1968), appeal denied, 23 N.Y. 645, 298 N.Y.S.2d 1027 (1969), a teacher's qualification for license as chairman of a high school English department was determined by a "teaching test" in which the teacher's performance was apparently judged by the performance of the students on achievement tests. This test assumes that the students' test performance was, to a measurable extent, "caused" by the conduct of the teacher. Res ipsa loquitur has also been used to establish negligence and cause in fact in medical malpractice cases. E.g., Ybarra v. Spangard, 25 Cal. 2d 486, 154 P.2d 687 (1944). Moreover, according to the Restatement (Second) of Torts, "[n]egligence and causation, like other facts, may . . be proved by circumstantial evidence." RESTATEMENT (SECOND) OF TORTS $\S 328 \mathrm{D}$, comment $b$ at $157(1965)$.

${ }^{223}$ See Restatement (Second) of Torts $\$ 328 \mathrm{D}$, comment $d$ at 152-59 (1965). See generally, C. JENCKs, supra note 11 .

${ }^{224}$ In a first-year course there would, of course, be no entering test scores. In that situation, however, we could hold constant performance in related subjects and assume a zero entering score for all classes. 
reading on the third-grade level and finish the year at the 3.2 grade level. Because the only relevant factor that varied between the groups was the teacher, it can be argued that the performance differential was due to differential teacher input.

The probative value of the comparison might be increased by a presentation of the performances of the defendant teacher's classes over a number of years. A showing that the performance of the plaintiff class is not significantly different from that of all of the defendant's classes strengthens the inference that the performance differential between the plaintiff class and the comparison class is attributable to the teacher, rather than to the plaintiff class's abnormality. ${ }^{225}$

\section{b. Objections to the Comparative Method}

Although the intergroup comparison permits the inference that the test score differences are due to different teacher input, ${ }^{226}$ the defendant may raise several objections to plaintiff's presentation. The defendant may argue the comparison has failed to hold constant a factor, other than teacher performance, which could have produced the differential test results. For example, the plaintiff class may have been abnormal for a group with the essential characteristics held constant in the comparison. Absent a showing that the defendant's classes have performed uniformly poorly over a multi-year period, ${ }^{227}$ the showing of comparatively poor test performance may indicate either that the inferior group was abnormal-perhaps the class had an unusually high number of troublemakers-or that the teacher was incompetent.

The possibility that the test score differentials were caused by something other than different teacher inputs, however, should not eliminate the availability of the comparative technique to the plaintiff in making a prima facie case. In view of the obvious difficulty of identifying comparison classes with all possible characteristics identical to those of the plaintiff class, once

${ }^{225}$ While a consistently inferior showing by defendant's students strengthens the claim that the teacher was the cause, such a showing may not always be essential or possible, as in the case of a first-year teacher or a previously competent teacher who becomes senile.

Although the method of proof outlined above would lend itself most readily to a class action suit, it is available to the individual plaintiff. For a discussion of the advantages and disadvantages of a class action suit, see note 23 supra.

${ }^{226}$ See Restatement (SECOND) of Torts $\S 328 \mathrm{D}$, comment $n$ at 165-66 (1965). See generally MCCoRMICK, supra note 221, §§ 336-47.

${ }^{227}$ Such a showing would be impossible in the cases of the incompetent first-year teacher and the elderly teacher who was competent until the present school year. 
the classes are shown to share the characteristics enumerated above, they should be presumed to be comparable in all other respects. The defendant should be permitted to rebut this presumption with evidence of the abnormality of the plaintiff class, for example, through the testimony of the principal that this was the worst behaved class he has seen in twenty years of school administration. ${ }^{228}$ It would then be for the jury to decide whether it was the teacher or the troublemakers who made the difference.

Although the defendant might point out that some studies suggest that teacher quality does not have a very great effect on achievement test scores, ${ }^{229}$ and that some of the other factors previously mentioned are more significant determinants of test-measured success, this technique would allow comparative measurement of whatever influence a teacher does have on test scores. The disagreement among authorities regarding the degree of correlation between test scores and cognitive skills, teacher quality, or economic success ${ }^{230}$ should not be crucial. The judge or jury will simply have to choose among conflicting expert opinions. As in antitrust cases, where the courts must rely on highly imperfect and debatable methods of proving cause and damages, ${ }^{231}$ perhaps test scores, though imperfect, are the best available indicators of how much students have learned under different conditions. Yet to the extent that courts remain unconvinced that poor test scores indicate the failure of students to learn fundamental skills, it is clear that a suit of this type, proven with the methods herein outlined, will not have a great likelihood of success.

The comparative technique might also be criticized for suggesting that an entire class was "harmed," while, in fact, the top or bottom ten percent may have performed better than they would have performed in comparison classes. For example, the teacher may have taught to the best or worst students and ignored the rest. Under the negligence standard developed in this Comment, ${ }^{232}$ however, it is questionable whether a teacher would be deemed negligent if a significant proportion of his or her students performed outstandingly. Even if some students did better with this teacher than they would have done in the

${ }^{228}$ See Lubell v. Nyquist, 31 App. Div. 2d 569, 294 N.Y.S.2d 961 (1968), appeal denied, 23 N.Y. 645, 298 N.Y.S.2d 1027 (1969).

${ }^{229}$ E.g., C. JENCKS, supra note 11.

${ }^{230}$ See, e.g., id.

${ }^{231}$ See Sax \& Hiestard, supra note 40 , at $886-87$.

232 Text accompanying notes 94-104 supra. 
comparison classes, there is no reason not to give a remedy to the students who suffered an educational loss. A comparative analysis broken down, for example, by IQ groups within a class, would permit identification of the "injured" groups for purposes of deciding who should receive remedial instruction.

\section{c. Proof of Causation of Harm on an Individual Basis}

If "cause in fact" and "harm" are proven on a class basis, relief in the form of remedial instruction or dismissal of an incompetent teacher could be awarded without a showing of harm to each individual student. If compensation is sought for diminished future earnings, however, the individual student probably must prove that he or she suffered harm because of the teacher's negligence.

Depending on the availability of the necessary data, the comparative method might be used to prove that an individual student's failure to learn was "caused" by the negligence of his teacher. Consider the following hypothetical. While performing an operation, a doctor negligently performs a certain procedure and the patient dies. Assume that when this operation is properly (non-negligently) performed, there is a two percent chance that the patient will die. When this particular act of negligence is committed, there is a fifty percent chance of death. Presumably there would be no objection to allowing a jury to find that the negligence of the doctor was the "cause in fact" of the patient's death. Even though there is some possibility that the patient would have died even if the doctor had not been negligent, it is more likely than not that the patient would not have died "but for" the doctor's negligence. ${ }^{233}$ Although the doctor may rebut the presumption created by the statistics by proving that the patient was among the two percent who would have died in a non-negligent operation, the possibility that without the doctor's negligence the patient would still have died $^{234}$ does not preclude a verdict for the patient.

This principle may be applied to education by isolating, in both the plaintiff and comparison classes, those students with the

${ }^{233}$ The preponderance of the evidence standard usually applied in civil cases is, according to McCormick, proof that leads the jury to find the existence of a contested fact more probable than its non-existence. MCCoRMICK, supra note 221, § 339, at 794 n.56.

${ }^{234}$ This possibility exists in many tort cases. In the typical case of the plaintiff's slipping on a wet floor that the defendant negligently failed to mop, the possibility that plaintiff would still have fallen if the floor had been dry does not of itself make proof of cause impossible. 
individual plaintiff's essential characteristics, and comparing the performance of those sub-classes. Suppose that in the comparison classes an average of ninety percent of the students with the same essential characteristics as the plaintiff progressed at least one grade level in reading in the fifth grade. In the plaintiff class, only forty percent of the students with the plaintiff's essential characteristics advanced at least one grade level. The plaintiff failed to advance a grade level in reading (and perhaps was held back a year). Because the teacher is the only causal factor not held constant between the two sub-classes, it can be inferred, in the absence of evidence to the contrary, that the different achievement rates are attributable to differential teacher input. While it is possible that the plaintiff would not have progressed at least one grade level even if he had been in one of the comparison classes, it is more likely than not that, but for the teacher's negligence, the plaintiff would have advanced at least one grade level. ${ }^{235}$

Perhaps the plaintiff should be required to introduce evidence that he is a typical or average member of the plaintiff sub-class-that there is no reason to place him within the ten percent who would have failed to progress at least a grade level even with a non-negligent teacher. For example, he might produce evidence that his behavior, diligence, and attentiveness were at least average for students with his "essential characteristics." This showing should at least create a rebuttable presumption or permit the inference that, "but for" the teacher's negli-

${ }^{235}$ See McCormick, supra note 221, § 339, at 794; Restatement (SECOND) OF TORTS $\S 328 \mathrm{D}$, comments $d \& e$ at $158-59$ (1965).

This more-likely-than-not determination may be derived as follows: Since $10 \%$ of those in the comparison class with plaintiff's essential characteristics (the "comparison sub-class") failed to advance one grade level, that percentage of those in the plaintiff class with plaintiff's essential characteristics (the "plaintiff sub-class") in excess of $10 \%$ who failed to advance one grade level was caused by the defendant teacher's input. Accordingly, since $40 \%$ of the plaintiff sub-class failed to advance one grade level, the failure of $30 \%(=40 \%-10 \%)$ of the plaintiff sub-class to advance one grade level was caused by the input of defendant teacher. The probability that the failure of a student in the plaintiff sub-class to advance one grade level was caused by the defendant teacher is the number of students in the plaintiff sub-class whose failure to advance one grade level was caused by the defendant teacher divided by the number of students in the plaintiff sub-class who failed to advance one grade level. Thus, the probability that a given student's failure to advance one grade level was caused by the defendant teacher is $75 \%\left(\frac{30 \% \times \text { number of students in plaintiff sub-class }}{40 \% \times \text { number of students in plaintiff sub-class }}=.75\right)$. Since $\mathbf{7 5 \%}$ is greater than $50 \%$, it is more likely than not that the failure of one of those in the plaintiff sub-class who failed to advance one grade level was caused by the defendant teacher's input. 
gence, the plaintiff would have advanced at least one grade level. The defendant could, of course, rebut this presumption with evidence that the plaintiff probably would not have advanced a grade level even if the teaching had been non-negligent because, for example, he was absent often. This method of proving causation of harm to the individual student does not provide a less precise indication of what would have happened "but for" the defendant's negligence than does reliance on general "world experience" in more usual negligence cases. ${ }^{236}$

${ }^{236}$ A problem with this method of proof arises when the standard of harm is not fixed. In the above example it was assumed that the minimum level of advancement was failure to advance one grade level. Suppose, however, that in the plaintiff sub-class $80 \%$ of the students failed to advance at least 1.2 grade levels while $40 \%$ of the students failed to advance at least 1.0 grade level. Assume further that $30 \%$ of the comparison sub-class failed to advance at least 1.2 grade levels while $25 \%$ of the comparison sub-class failed to advance at least 1.0 grade level. Under these circumstances, the probability that the failure of a student in the plaintiff sub-class to advance at least 1.2 grade levels was caused by the teacher is $62.5 \%$. The probability that the failure of a student in the plaintiff sub-class to advance at least 1.0 grade level was caused by the teacher, however, is $38 \%$. Therefore, although it is more likely than not that a student's failure to advance 1.2 grade levels was caused by the defendant teacher, it is more likely than not that a student's failure to advance 1.0 grade level was not caused by the defendant teacher. In such circumstances the choice of the minimum level of advancement with reference to which the harm will be identified-the choice between failure to advance at least 1.0 and 1.2 grade levels in this example-is crucial, and thus susceptible to manipulation.

If, fortuitously, the percentage of students in the comparison sub-class failing to advance beyond each level remains in a constant proportion to the percentage of students in the plaintiff sub-class failing to advance beyond each respective level, this problem is guaranteed not to arise. More realistically, even if the proportion is not constant, it may not vary sufficiently to change the more likely than not determination. Suppose, for example, that $80 \%$ of the plaintiff sub-class failed to advance at least 1.2 grade levels, $40 \%$ of the plaintiff sub-class failed to advance at least 1.0 grade level, $30 \%$ of the comparison sub-class failed to advance at least 1.2 grade levels, and $10 \%$ of the comparison sub-class failed to advance at least 1.0 grade level. Although the probability that the defendant teacher caused the failure of a student in the plaintiff sub-class to advance 1.2 grade levels is $62.5 \%$, while the probability that the defendant teacher caused the failure of a student in the plaintiff sub-class to advance 1.0 grade level is $75 \%$, in both cases it is more likely than not that the teacher was the cause. If the plaintiff can establish harm due to teacher inputs over most of the range of progress levels, he might succeed in making out a prima facie case even when results conflict between any two levels.

${ }^{237}$ See notes 94-104 supra \& accompanying text. The statistically determined average worst performance in comparison classes would naturally be the product of performances above and below the average, all of which represent the worst performances in each class or program in the comparison classes, including performances which might be found negligent. If graphed, these performances might appear approximately as a normal curve with the mean being the standard of minimum professional competence for communities of comparable essential characteristics. Teachers whose performances fall above the mean will not be found negligent even though their performances are the worst in their respective schools. Arguably, because of the imperfection of measurement, teachers whose performances are clustered just below the mean should not be found negligent. Teachers whose performances fall in the extreme tail of the curve below the mean would clearly be negligent. The point "significantly" below the mean at which 


\section{Proof of Negligence}

\section{a. The Comparative Method}

The comparative method outlined above does not establish teacher negligence; it establishes only that the quality of a teacher's performance is inferior to that of the teachers of comparison classes. To establish negligence, the plaintiff must prove that the defendant's performance is worse than that of the minimally acceptable teacher in the same or similar communities. In light of the comparative method of proof, this definition of negligence may be translated into the following standard: A teacher is negligent if it is proven that his or her performance falls significantly below the average worst performance of teachers in comparison classes identical in all essential respects with the plaintiff class. ${ }^{237}$

One method of proving that the defendant teacher's performance falls below this standard relies on an inference of the existence of an unobserved fact from proof of the existence of an observed fact. The inference, similar to that employed under the doctrine of res ipsa loquitur, ${ }^{238}$ is that one teacher's students do not perform significantly worse than the average worst performance of other teachers' students identical in all essential respects unless the individual teacher's performance is below the average worst performance of teachers in the community. ${ }^{239}$ Given this inference and standard of negligence, negligence may be established by proof that the performance of the plaintiff class falls significantly below the average worst performance of the comparison classes. Medical malpractice cases provide ample authority for proving negligence by circumstantial evidence. ${ }^{240}$

Suppose that in a ghetto school over a ten-year period, the first-year French classes of teacher $A$ have averaged in the fifth percentile on year-end achievement tests. Average scores in individual years ranged between the fourth and sixth percentile. In the comparison schools, the students of the worst teachers have

performance becomes inexcusable would have to be determined in the courts through litigation. Although policy would play the major role in the fixing of this point, a plaintiff might strengthen his case by showing, when the requisite data is available, that defendant's performance is more than one or two standard deviations below the mean.

${ }^{238}$ See sources cited note 219 supra.

${ }^{239}$ See Restatement (Second) of Torts \& $328 \mathrm{D}$, comments $f$ \& $g$ at 160-62 (1965).

${ }^{240}$ See Ybarra v. Spangard, 25 Cal. 2d 486, 154 P.2d 687 (1944); W. Prosser, supra note 25, § 39, at 226-28; see note 222 supra. But see Olson v. North, 276 Ill. App. 457, (1934); Wade, supra note 52, at $228 \&$ nn.67, 68. 
averaged in the fifteenth percentile and the comparison groups overall have averaged in seventeenth percentile. Unless it is shown that these test results were "caused" by a factor other than teacher input, it reasonably could be concluded that the performance of teacher $A$ failed to meet minimum professional standards.

\section{b. Lack of Certification}

The extent to which lack of certification ${ }^{241}$ should be independent evidence of a teacher's negligence is unclear. It has been suggested that an uncertified or unlicensed professional should be held strictly liable for injuries caused in the performance of a function requiring certification or license. In Biakanja v. Irving, ${ }^{242}$ for example, the defendant, who was not licensed to practice law as required by statute, was held to be negligent per se in a suit arising from his drafting of a faulty will. In the education context, this view implies that an uncertified teacher would be negligent per se or strictly liable if his classes failed to obtain the average level of performance for students with the same essential characteristics. ${ }^{243}$

Other authorities suggest that lack of certification is evidence of negligence where injury results from performance of a function for which certification is required by law. ${ }^{244}$ Some support for the application of this theory is provided by Kobylski $v$. Board of Education, ${ }^{245}$ in which a New York court held that the failure of a teacher to have a valid teaching certificate could constitute substantial evidence of incompetence in a dismissal proceeding. This theory could result in finding an uncertified teacher negligent where he followed the same procedures and obtained the same results as a certified teacher, who might not be found negligent.

Perhaps the best view is that of the majority of the New York Court of Appeals in Brown v. Shyne:246 Lack of statutorily required certification is evidence of negligence only where it is

${ }^{241}$ It has been suggested that there is a presumption of competence on the part of a properly certified teacher. E. Reutrer \& R. Hamilton, supra note 14 , at 450 . This presumption, however, must be subject to rebuttal by the kinds of evidence discussed in this section.

242310 P.2d 63 (Cal. Dist. Ct. App. 1957), aff'd in part, 49 Cal. 2d 647, 320 P.2d 16 (1958).

${ }^{243}$ See text accompanying notes 221-24 supra.

${ }^{244}$ E.g., Brown v. Shyne, 242 N.Y. 176, 151 N.E. 197 (1926) (Crane, J., dissenting).

24533 App. Div. 2d 603, 304 N.Y.S.2d 453 (1969).

246242 N.Y. 176,151 N.E. 197 (1926). 
logically relevant to a showing that the defendant failed to meet the standard of conduct required of certified members of the profession-for instance, where the defendant was unable to obtain a certificate because of unsatisfactory practice teaching. The theories that impose a higher standard on uncertified teachers, however, may have the arguably desirable effect of discouraging uncertified people from teaching.

The extent to which lack of certification indicates negligence by the officials who hired the uncertified teacher is also unclear. The determination of whether hiring an uncertified teacher constitutes negligence per se, evidence of negligence, or nothing in itself, might depend on the statutory requirements for hiring and whether or not the hiring of uncertified teachers should be discouraged. It may also be asked whether the fact that an incompetent teacher is certified conclusively proves that the school district was not negligent in hiring him (apart from possible vicarious liability). It can be argued that a school district is acting per se reasonably where it hires a certified teacher because it can reasonably rely on the teaching certificate as conclusive proof that the teacher is minimally competent. While certification may be a defense against a claim of administrator negligence during the first year of the teacher's employment, a school district clearly could be negligent in retaining or rehiring a certified teacher who performed poorly during the first year. Furthermore, a school district might be found negligent for hiring a certified but incompetent teacher of whose past or probable incompetence school officials had knowledge, perhaps from poor letters of recommendation.

\section{c. Other Types of Proof}

Evaluations of a teacher by his or her principal or supervisor might provide other evidence of teacher negligence. ${ }^{247}$ If, on the basis of observation, a principal or supervisor rated a teacher's performance unsatisfactory, these evaluations might be available to the plaintiff as evidence of the teacher's negligence or incompetence; moreover, if a principal or supervisor rated a teacher unsatisfactory but failed to dismiss the teacher "for cause" or rehired the teacher, this would seem to be evidence that the supervisor or principal was negligent.

As was suggested earlier, ${ }^{248}$ the unexcused failure of a

${ }^{247}$ See Conley v. Board of Educ., 143 Conn. 488, 123 A.2d 747 (1956), in which a teacher's supervisor testified about the teacher's shortcomings in a dismissal proceeding.

${ }^{248}$ Notes 145-63 supra \& accompanying text. 
teacher or school official to conform to statutes or regulations enacted to protect students against the risk of not learning may constitute negligence per se or evidence of negligence. ${ }^{249}$ If, for example, a teacher failed to follow a school district regulation requiring that a certain percentage of class time be used for reading instruction, and the students fell behind their grade level in reading, violation of the regulation may constitute negligence per se or evidence of negligence. Failure of a school official to follow statutorily prescribed hiring criteria also may constitute negligence per se or evidence of negligence if he hires an incompetent teacher who causes educational harm to students. On the other hand, compliance with statutes and regulations does not preclude a finding of negligence. ${ }^{250}$

Where a teacher has taken a "teaching test,"251 his performance on the test might be introduced (along with expert testimony) as evidence of negligence or incompetence. If the defendant performed well on the test, he might introduce the results to prove his competence or non-negligence.

Teacher negligence might also be established by evidence that the teacher did not follow conventional teaching methods, or at least methods recognized by a substantial portion of the profession. ${ }^{252}$ In Gardner v. State, ${ }^{253}$ for example, the state of New York was held liable on a negligence theory for injuries sustained by a student caused by the failure of a gym teacher to give gymnastic instruction according to customary methods. ${ }^{254}$ This is not to say, of course, that mere deviation from traditional teaching methods alone should constitute negligence. ${ }^{255}$ If a re-

249 See Restatement (Second) OF ToRTs $\$$ 286, 288 B (1965).

${ }^{250} \mathrm{Id}$. $\S 288 \mathrm{C}$.

${ }^{251}$ See Lubell v. Nyquist, 31 App. Div. 2d 569, 294 N.Y.S.2d 961 (1968), appeal denied, 23 N.Y. 645, 298 N.Y.S.2d 1027 (1969); note 222 supra.

${ }^{252}$ See notes 94-104 supra \& accompanying text.

${ }^{253} 281$ N.Y. 212, 22 N.E.2d 344 (1939). See Keesee v. Board of Educ., 37 Misc. 2d 414,235 N.Y.S.2d 300 (Sup. Ct. 1962), in which a gym teacher's deviation from a syllabus was considered evidence of negligence.

${ }^{254}$ It has been suggested that an attorney's deviation from customary methods should constitute negligence if he fails to accomplish the desired objective. Wade, supra note 52 , at 227 \& n.58. A recent law review comment, moreover, has contended that a professional's deviation from established procedures should create a rebuttable presumption of negligence. Professional Negligence, supra note 51, at 645; see generally Curran, supra note 95, at 4-6. A possible objection to using deviation from conventional procedures as an indicium of negligence is that it might discourage experimentation and restrict development of new and better educational methods. For an answer to this objection, see text accompanying notes 52-55 supra.

${ }^{255}$ Under some circumstances there may be constitutional problems with requiring a teacher to follow particular teaching methods. $C f$. Webb v. Lake Mills Community School Dist., 344 F. Supp. 791 (N.D. Iowa 1972). 
spected segment of the educational community recognizes or adheres to the method, the deviation should not be considered negligent, even if, in a particular case, students learned less than they probably would have if taught by conventional methods.

\section{Private Education}

The case of the public school student presents the most difficulties and has the least chance of success of any suit by a student who fails to learn because of teacher negligence. The private school student who fails to learn because of teacher negligence could use most of the legal arguments and methods of proof developed in the public school context $\mathrm{t}^{256}$ unencumbered by several of the difficulties encountered in the public school suit. Governmental immunity would not bar recovery, although charitable immunity doctrines might; ${ }^{257}$ the doctrine of respondeat superior is more likely to render the private school liable for the acts and omissions of its teachers than the public school; and the existence of a contract upon which to base a breach of contract theory is not at issue. ${ }^{258}$ It is even possible in the private school case that the promise of non-negligent instruction will be express, either oral or written. If not, it is perhaps easier to find an implied promise of non-negligent instruction than in the public school situation. Furthermore, teacher negligence aside, it may be possible to find a promise or warranty of a minimum level of student performance or subsequent educational opportunity, either expressed in the contract or implied by advertising or other promotional representations. ${ }^{259}$ In the event of breach, the amount of tuition paid is a measure of damage seemingly less speculative than any of the damages assertible in the public school situation. ${ }^{260}$

A troublesome feature of the private school case is that the private school is not as effective a risk bearer or distributor as a

${ }^{256}$ Obviously, liability could not be based on the kinds of statutes discussed in text accompanying notes $145-63$ supra.

${ }^{257}$ See W. ProssER, supra note 25, § 133.

${ }^{258}$ See, e.g., Arthur Murray, Inc. v. Parris, 243 Ark. 441, 420 S.W.2d 518 (1967) (student recovered prepaid tuition for unused lessons because dance studio breached contract by failing to provide competent instruction); Olson v. Glen Falls Ins. Co., 181 Cal. App. 2d 165, 5 Cal. Rptr. 233 (Dist. Ct. App. 1960); Sciortino v. Leach, 242 So. 2d 269 (La. Ct. App. 1970).

${ }^{259}$ See Arthur Murray, Inc. v. Parris, 243 Ark. 441, 420 S.W.2d 518 (1967). See generally Note, Developing Protection for the Consumer of Future Services, 72 Colum. L. Rev. 926 (1972).

${ }^{260}$ See id.; Olson v. Glen Falls Ins. Co., 181 Cal. App. 2d 165, 5 Cal. Rptr. 233 (Dist. Ct. App. 1960); Stad v. Grace Downs Model \& Air Career School, 65 Misc. 2d 1095, 319 N.Y.S.2d 918 (Queens County Civ. Ct. 1971). 
public entity. While tuition refunds might not cripple the school, the broader damages discussed in the public school context might be ruinous. If insurance is available, however, a suit for failure to learn remains more likely to succeed in the private than in the public school context. This greater likelihood of success also applies to suits against private colleges and universities. $^{261}$

A student in a professional or occupational training course also might bring a successful suit to recover for his failure to learn. For example, a student in a computer repair course would have a strong contract or tort case if the techniques he was taught applied only to computers of a type no longer used by anyone. ${ }^{262}$ Problems of proof are clearly less troublesome than in the public school situation. Damages would not be speculative, and could encompass not only tuition but provable loss of income if the student gave up a job in expectation of learning a new occupation. If a technical training course falsely represents that graduates will find employment, deceit or negligent misrepresentation would provide a plausible basis for an action for tuition refund or more extensive damages. ${ }^{263}$

A final possible situation in which a suit for failure to learn because of teacher negligence could be brought with the legal theories and methods of proof outlined in this Comment might arise where a bar review course fails to teach the students the correct law. An important change in the law, for example, is not incorporated into the review course. The negligence of the instructor seems easily provable. ${ }^{264}$ The comparative methods could be used to prove cause and harm. Suppose the normal bar exam pass rate of similarly composed review classes is eighty percent and the pass rate in the plaintiff's incorrectly instructed class was thirty percent. Over a ten-year period the lowest pass rate of any non-negligently instructed class was seventy percent. Out of a class of one hundred students who took the course, it could be argued that twenty would have failed even if the instruction had been non-negligent, and the failure of the remaining fifty is attributable to the negligent instruction. Thus, all

${ }^{261}$ See Paynter v. New York Univ., 64 Misc. 2d 226, 314 N.Y.S.2d 676 (N.Y. County Civ. Ct. 1970), rev'd, 66 Misc. 2d 92, 319 N.Y.S.2d 893 (App. T. 1971).

${ }^{262}$ See Note, supra note 259; $c f$. Sciortino v. Leach, 242 So. 2d 269 (La. Ct. App. 1970).

${ }^{263}$ See Stad v. Grace Downs Model \& Air Career School, 65 Misc. 2d 1095, 319 N.Y.S.2d 918 (Queens County Civ. Ct. 1971); Brown v. Search, 131 Wis. 109, 111 N.W. 210 (1907); W. Prosser, supra note 25, §§ 109-10, at 728-36.

${ }^{264}$ See text accompanying notes $237-55$ supra. 
things being equal, it is more likely than not that the failure of any particular student was caused by the negligent instruction. Of course, it would be open to the defendant to prove that a particular student's failure is attributable to something other than the negligence of the instruction, for instance, the student's failure to attend the classes. ${ }^{265}$ In the case of a homogeneous group, however, any member of the class could use this method to establish that, more likely than not, he would have passed "but for" the negligence of the instructor. In a negligence action, proximate cause would easily be established, since the risk created by negligent instruction in a bar review course clearly is that students will fail the bar exam.

The plaintiff's case might be strengthened by a showing that he was an outstanding law student who had diligently prepared for the bar exam. A less outstanding plaintiff should try to show that he was typical of the group who took the course, that is, that there is no reason to believe that he was more likely to fail than anyone else.

Calculation of damages is also easier in this situation than in the public school context. Beyond tuition refund, the students who failed the bar exam could be compensated for income lost while they retook the course and waited for the exam results. Recovery might also be possible, on a more speculative basis, for loss of a job because of failing the bar exam. Finally, even those who passed the exam might be able to recover tuition on a contract theory, because they did not receive that for which they bargained.

\section{ConCLUSION}

At the present time, the problems involved in bringing a suit for failure to learn because of teacher negligence or incompetence may seem insurmountable. Traditional legal principles, however, provide ample guidance for fashioning a viable cause of action.

First, failure to learn is not a harm beyond the law's remedial capabilities. The replacement of incompetent by competent teachers, the provision of, or payment for, remedial instruction, and monetary compensation for diminished future income could "make whole" public school students who have suffered a loss of educational benefits.

Second, tort law, contract law, and mandamus provide legal theories on which a suit for failure to learn might be based. A 
negligence suit stands the most chance of success; various statutory, common law, and scholarly authorities support the contention that school districts and teachers should be held liable for the failure of students to learn because of the negligence of the teachers. The standard of acceptable instruction should be comparative, that is, the level of skill and learning of the minimally acceptable teacher in the same or similar communities. In limited circumstances, causes of action based on intentional tort or misrepresentation may also be available. Contract law may supply the public school student with a cause of action if the factfinder can be persuaded of the existence of implied contracts between the student and the teacher or between the student and the school district, with an implied promise of non-negligent instruction. Although in many cases the contract theory may be less plausible than the tort theory, the contract approach has several advantages: Governmental immunity, which may bar recovery in tort, might not preclude a successful contract action; courts may be more willing to allow recovery for loss of an expectancy or benefit in contract than in tort; defenses such as contributory negligence or assumption of risk may bar recovery in tort but not in contract; and statutes of limitations are generally longer for contract actions. A contract theory would, of course, be of more use to a private school student than to a public school student. Finally, in narrowly defined circumstances, mandamus may provide minimal relief.

Third, there are several methods of proving teacher negligence and causation of harm. The latter can be established if the plaintiff proves that a class of which he was a member performed significantly worse than did classes identical in all essential respects except that they were not taught by the defendant teacher. Negligence can be established if the plaintiff proves that the teacher's performance fell significantly below the average worst performance of teachers in classes identical to the plaintiff's in all essential respects. Lack of certification, a supervisor's poor evaluations, failure to conform to statutory educational requirements, and failure to use recognized teaching methods might provide other evidence of negligence.

The legal framework for a cause of action for failure to learn is supported by strong policy considerations, including the importance of education, the ability of teachers and school districts to bear or spread the costs of students' failure to learn, and the desirability of deterring negligent teaching and the hiring of incompetent teachers. 
The novelty of the theories advanced in this Comment does not condemn educational malpractice suits to an eternity of sustained demurrers and motions to dismiss for failure to state a cause of action. Dean Prosser's tribute to the flexibility of tort law is an acknowledgement of the dynamism of the common law generally:

[T] he progress of the common law is marked by many cases of first impression, in which the court has struck out boldly to create a new cause of action, where none had been recognized before. . . . The law of torts is anything but static, and the limits of its development are never set. When it becomes clear that the plaintiff's interests are entitled to legal protection against the conduct of the defendant, the mere fact that the claim is novel will not of itself operate as a bar to recovery. ${ }^{266}$

${ }^{266} \mathrm{~W}$. Prosser, supra note $25, \S 1$, at 3 (footnote omitted). 